\title{
Geoquímica e petrologia dos metagranitos do Complexo Encantadas, Santana da Boa Vista, (RS): a evolução de uma margem continental ativa no Paleoproterozóico
}

\author{
Marcelo Lusa', Ruy Paulo Philipp ${ }^{2}$ \& Lauro Valentim Stoll Nardi ${ }^{2}$
}

\begin{abstract}
Resumo O Complexo Encantadas é uma unidade Paleoproterozóica constituída por gnaisses tonalíticos, trondhjemíticos e dioríticos com presença subordinada de anfibolitos e rochas metaultramáficas ricas em hornblenda. Este complexo é cortado por corpos tabulares de metagranitos porfiríticos e equigranulares que se encontram posicionados ao longo de uma zona de cisalhamento dúctil de disposição suborizontal. Esta estrutura define o contato entre os Complexos Encantadas e Porongos, respectivamente, infra e supra-estrutura do Domo de Santana da Boa Vista. Os metagranitos têm composição cálcico-alcalina médio a alto-K e caráter levemente peraluminoso. A evolução como termos independentes indica que os metagranitos representam unidades petrológicas distintas, sendo afetados por processos de fracionamento de plagioclásio, biotita, zircão e apatita. Os metagranitos apresentam enriquecimento em ETRL e empobrecimento em ETRP, com valores elevados de Ba, $\mathrm{Rb}, \mathrm{Sr}, \mathrm{U}$ e Th, anomalias negativas de $\mathrm{Nb}$ e Ti, dispondo-se no campo das rochas geradas em ambientes de arco magmático. Os dados estruturais indicam que os metagranitos tiveram uma evolução complexa, e sua colocação é contemporânea ou anterior a $\mathrm{D}_{1} \mathrm{e}$, portanto, de acordo com os dados geocronológicos disponíveis, sua idade situa-se próxima de $2.1 \mathrm{Ga}$, que é a idade presumível do metamorfismo da fácies anfibolito, interpretado aqui como um evento orogênico, provavelmente colisional. Os metagranitos porfiríticos e equigranulares juntamente com os gnaisses dioriticos, tonaliticos e trondhjemiticos do Complexo Encantadas constituem uma associação magmática gerada em ambiente de margem continental ativa, cujo magmatismo está associado a fontes mantélicas metassomatisadas por fluídos derivados de subducção litosférica durante o Paleoproterozóico.
\end{abstract}

Palavras-chave: Granitos, Geoquímica, Milonitos, Complexo Encantadas, Paleoproterozóico, Terreno Tijucas.

\begin{abstract}
Geochemistry and petrology of porphyritic and equigranular metagranites of Encantadas Complex, Santana da Boa Vista (RS), southern Brazil: an evolution of active continental margin in the Paleoproterozoic. The Encantadas Complex is a Paleoproterozoic unit constituted by tonalitic, trondhjemitic and dioritic gneisses with rare presence of amphibolites and hornblende rich metaultramafic rocks. This complex is cut by tabular bodies of porphyritic and equigranular metagranites and are positioned along a ductile shear zone with suborizontal disposition. This structure defines the contact between the Encantadas and Porongos complexes, respectively, infrastructure and suprastructure of Santana da Boa Vista Dome. The metagranites have medium to high-K calc-alkaline composition and slightly peraluminous character. The evolution as independent terms indicates that metagranites represent distinct petrologic units, being affected by fractionating process involving plagioclase, biotite, zircon and apatite. The metagranites present enrichment in LRRE and decrease of HREE, with high values of $\mathrm{Ba}, \mathrm{Rb}, \mathrm{Sr}, \mathrm{U}$ and $\mathrm{Th}$, negative anomalies of $\mathrm{Nb}$ and Ti, falling in the magmatic arc granites field. Structural data indicate that metagranites had a complex evolution, and its emplacement is simultaneously or more ancient with $\mathrm{D}_{1}$ event, according to disposable geochronological data, its age is nearly to $2.1 \mathrm{Ga}$. This age is interpreted as an orogenic metamorphic event, probably of collisional type. Porphyritic and equigranular metagranites together with gneisses of Encantadas Complex constitute an active continental margin arc association, whose magmatism is related to metassomatised mantelic sources affected by fluids derivative of lithosphere subduction during the Paleoproterozoic times.
\end{abstract}

Keywords: Granites, Geochemistry, Mylonites, Encantadas Complex, Paleoproterozoic, Tijucas Terrane.

INTRODUÇÃO Na região de Santana da Boa Vista afloram rochas gnáissicas e metagranitóides de idade $\mathrm{Pa}-$ leoproterozóica e rochas metavulcanossedimentares pertencentes ao embasamento do Escudo Sul-rio-grandense (Soliani Jr. 1986; Remus et al. 1990; Fernandes et al.
1992; Hartmann et al. 2000; Chemale et al. 2000). Estas unidades fazem parte do Terreno Tijucas, unidade central do Cinturão Dom Feliciano, dispondo-se com uma forma alongada segundo a direção N30 ${ }^{\circ} \mathrm{E}$, estendendo-se para o estado de Santa Catarina e para o Uruguai (Fig.

1 - Universidade Federal do Rio Grande do Sul, Instituto de Geociências, Pós-Graduação em Geociências, Porto Alegre (RS), Brasil.

E-mail: brincuringa@gmail.com

2 - Universidade Federal do Rio Grande do Sul, Instituto de Geociências, Centro de Estudos em Petrologia e Geoquímica (CPGq), Porto Alegre (RS), Brasil. Pesquisadores do CNPq. E-mail: ruy.philipp@ufrgs.br; lauro.nardi@ufrgs.br 
1). Este terreno está representado na litoestratigrafia do RS pelos Complexos Encantadas e Porongos, respectivamente, infra e supraestrutura do embasamento nesta porção do escudo.

Definidas originalmente como Gnaisse Encantadas por Ribeiro et al. (1966), estas litologias ocupam a porção central e infra-estrutural do Domo de Santana da Boa Vista (Jost \& Bitencourt 1980), uma estrutura alongada segundo a direção $\mathrm{N} 30^{\circ} \mathrm{E}$, com aproximadamente $50 \mathrm{~km}$ de extensão e cerca de 8 a $15 \mathrm{~km}$ de largura (Fig. 2).

O Complexo Encantadas (Chemale Jr. 2000) é composto pelo Gnaisse Encantadas e por metagranitóides miloníticos de composição monzogranítica e sienogranítica. O Gnaisse Encantadas caracteriza-se por uma associação de gnaisses tonalíticos e trondhjemíticos, com ocorrência subordinada de gnaisses dioríticos, anfibolitos máficos e metaultramafitos ricos em hornblenda (hornblenditos) (Philipp et al. 2008). Os gnaisses são cortados por dois grupos de granitóides milonitizados de composição monzo e sienogranítica. Estes granitóides foram referidos como Granitóides Milonitizados de Santana da Boa Vista (Machado et al. 1987), constituindo corpos individualizados e também lentes de espessura centimétricas a métricas. As relações intrusivas são definidas por relações discordantes e de corte, com disposição em baixo ângulo com relação ao bandamento do Gnaisse Encantadas (Machado et al. 1987; Porcher \& Fernandes 1990; Remus et al. 1990). Os granitóides têm formas alongadas, concordantes com o alongamento do Domo de Santana, dispondo-se ao longo do limites do Complexo Encantadas com o Complexo Porongos (Fig. 3). São identificados dois tipos de metagranitos.
Os metagranitos porfiríticos são dominantes, possuem composição monzogranítica e textura blastoporfirítica caracterizada por augen de megracristais de K-feldspato deformados envoltos por uma matriz de textura protomilonítica a milonítica composta por quartzo, plagioclásio e biotita. Os metagranitos equigranulares constituem um corpo principal na porção sudeste do domo, ocorrendo, entretanto, em outras áreas como corpos tabulares de espessuras centimétricas a métricas. Possuem composição sienogranítica, são leucocráticos e apresentam textura blastoequigranular protomilonítica a milonítica. As formas tabulares e o paralelismo entre as foliações magmáticas e tectônicas indicam que os metagranitos tem um posicionamento sincrônico a uma das principais fases de deformação regional que afeta o Complexo Encantadas, como será discutido posteriormente.

O contato entre os Complexos Encantadas e Porongos ocorre através de uma zona de cisalhamento dúctil de baixo ângulo, cuja movimentação altera as relações estratigráficas originais e imprime transformações de natureza milonítica. O grau metamórfico do Complexo Encantadas é definido pelos anfibolitos, que apresentam paragêneses representativas de mais de um evento termal, comumente acompanhado por intensa deformação (Philipp et al. 1995). O pico de metamorfismo regional atingiu condições de fácies anfibolito médio a superior. O posicionamento destes corpos está associado ao desenvolvimento de extensas zonas de cisalhamento dúcteis suborizontais, formando uma trama milonítica de temperatura elevada, compatível com a fácies anfibolito médio. Fases deformacionais mais tardias, associadas com condições metamórficas da fácies xistos verdes e anfibolito inferior, estão registradas

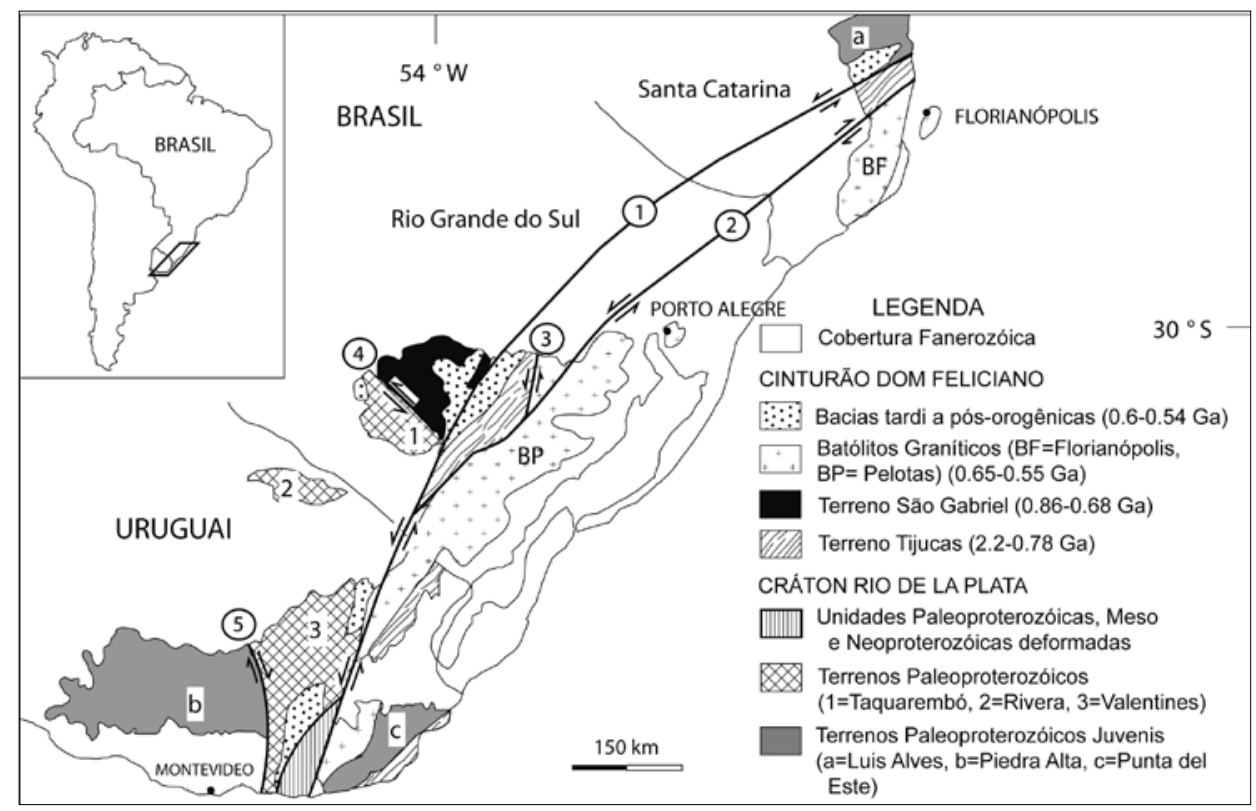

Figura 1 - Principais unidades geotectônicas do Sul do Brasil e Uruguai. Legenda: $a=$ Terreno Luis Alves, $b=$ Terreno Florida, $c=$ Terreno Punta del Este $1=$ Terreno Taquarembó, $2=$ Terreno Rivera, $3=$ Terreno Valentines. Compilado de Hartmann et al. 2007. 


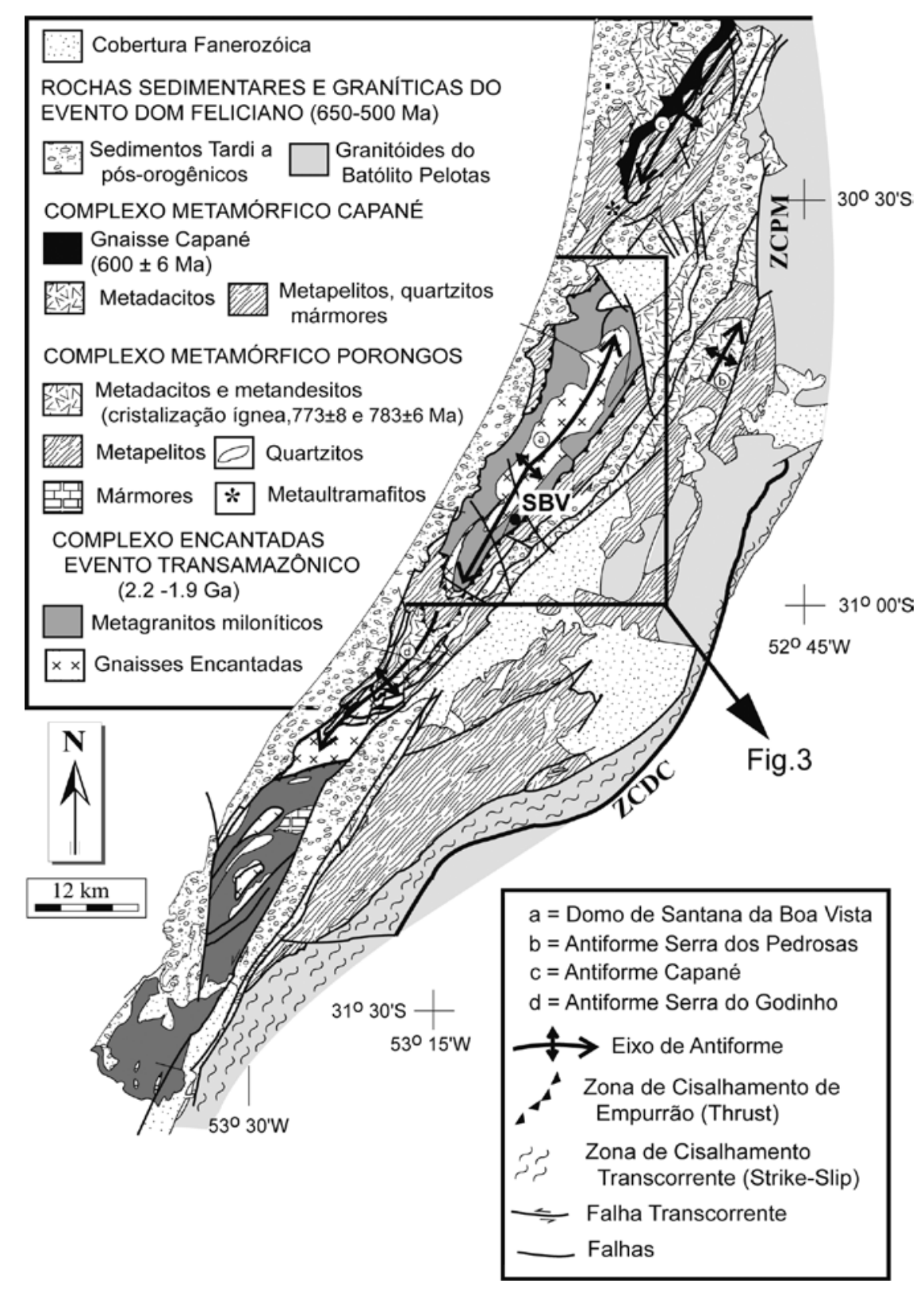

Figura 2 - Mapa geológico do Terreno Tijucas destacando o Domo de Santana da Boa Vista e as rochas do Complexo Encantadas. Modificado de Chemale Jr. (2000).

também nas rochas supracrustais do Complexo Porongos (Remus et al. 1990).

O principal objetivo deste trabalho é caracterizar os metagranitos porfiríticos e equigranulares do Complexo Encantadas a partir de dados petrográficos, estruturais e geoquímicos. A reunião destas informações permitirá a determinação da série magmática, investigação de processos de fracionamento e das suas relações estratigráficas e tectônicas com relação aos gnaisses do Complexo Encantadas.

TRABALHOS ANTERIORES A ocorrência de rochas gnáissicas na região de Santana da Boa Vista foi mencionada por Carvalho (1932) e por Leinz \& Pinagel (1945). O levantamento regional desenvolvido por
Ribeiro et al. (1966) caracterizou a Formação Encantadas como uma unidade composta por ortognaisses de médio grau. O mapeamento geológico e estrutural do Gnaisse Encantadas por Jost \& Bitencourt (1980) reconheceu sua exposição como decorrência de uma estrutura antiforme com duplo caimento denominada Domo de Santana. Os autores identificaram também a zona de falha principal de baixo ângulo, responsável pelo contato entre infra e supra-estrutura. Em função da intensa transformação milonítica os metagranitos foram interpretados como metarcóseos e xistos quartzofeldspáticos (Jost \& Bitencourt 1980).

O caráter intrusivo dos granitóides no Gnaisse Encantadas foi ressaltado por Machado et al. (1987) que os descreveram como “... corpos individualizáveis 

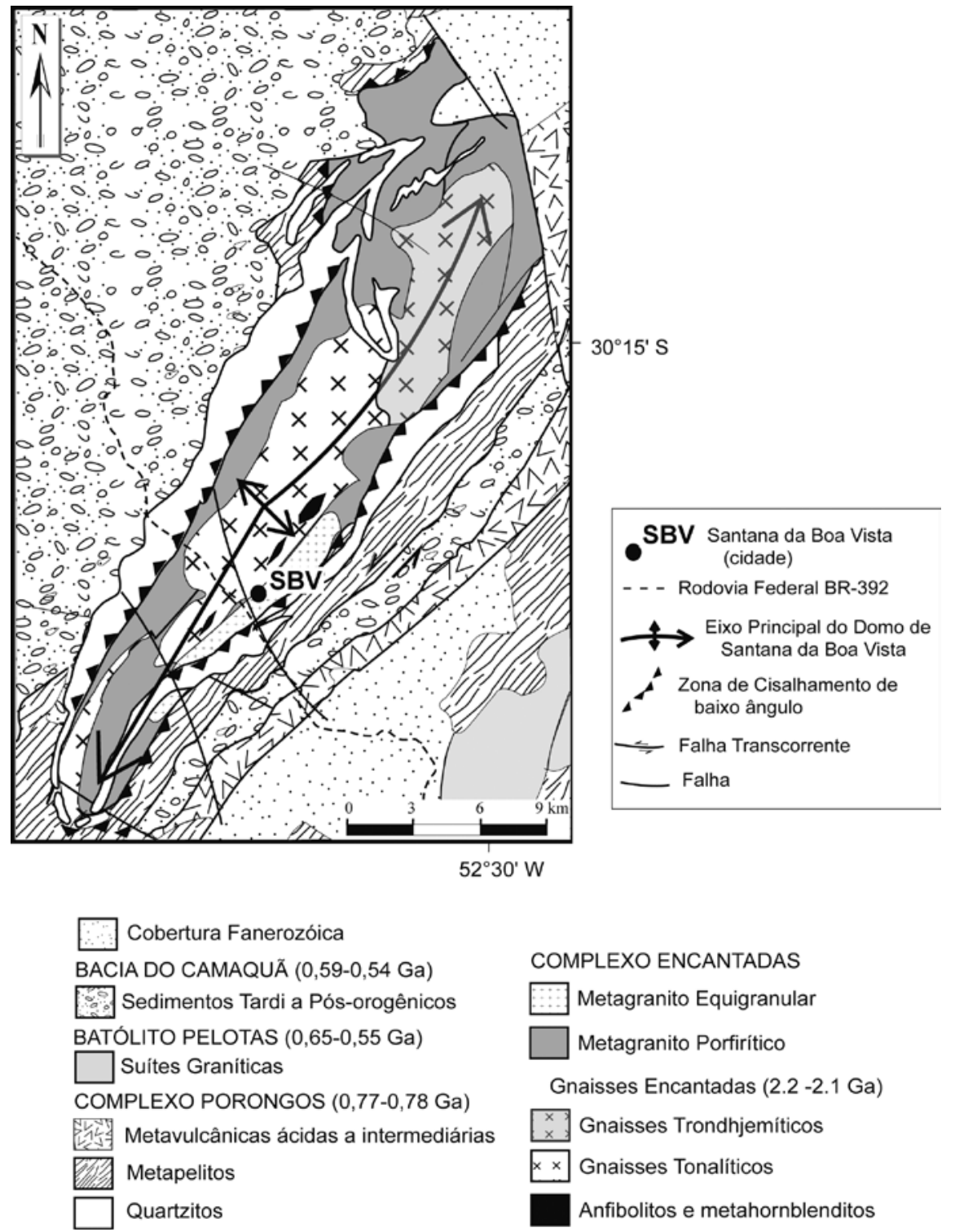

Figura 3 - Mapa geológico da região do Complexo Encantadas, destacando a ocorrência dos metagranitos (Fonte: Philipp et al. 2008).

e lentes de granitos a granodioritos róseos a acinzentados com albita-quartzo-biotita-muscovita-epidoto na matriz". Os autores descrevem relações de intrusão oblíquas em relação ao bandamento gnáissico $\left(\mathrm{Sb}_{1}\right)$ e definem condições metamórficas da fácies xistos verdes para os eventos deformacionais ocorrentes. A geração dos granitos é interpretada como associada a fases precoces da deformação brasiliana na região caracterizando os granitóides como pré-tectônicos.

Os levantamentos geológicos da UFRGS (inédito), sintetizados por Porcher \& Fernandes (1990) caracterizaram as relações de contato entre as rochas gnáissicas e as rochas metavulcano-sedimentares da cobertura como uma zona de cisalhamento dúctil de baixo ângulo produto do escape tectônico promovido por um evento de colisão continental de idade Brasiliana. A deformação dúctil nos metagranitóides deu origem a foliações miloníticas e lineações de estiramento indicando a posição do plano suborizontal e a direção (NE-SW) do fluxo nessas unidades. Sistemas de porfiroclastos assimétricos (feldspato) indicam uma cinemática lateral esquerda. As condições superiores do metamorfismo, da fácies anfibolito, são reconhecidas por Porcher \& Fernandes (1990), que descrevem microestruturas geradas por deformação dúctil nos porfiroclastos de feldspato dos granitóides que estão milonitizados.

Não existem dados geocronológicos disponíveis para a idade ígnea dos granitos que cortam os Gnaisses Encantadas. Os dados de U-Pb SHRIMP em zircões dos gnaisses tonalíticos fornecem idades de $2263 \pm 18$ Ma e $2363 \pm 6$ Ma para os núcleos ígneos, enquanto os cristais metamórficos apresentam idades de $2045 \pm 10$ Ma e $2021 \pm 11$ Ma (Chemale Jr. 2000). Mais recentemente Hartmann et al. (2003) obtiveram 
idades U-Pb SHRIMP de $2256 \pm 8$ Ma para zircões dos gnaisses tonalíticos e de $2257 \pm 12$ Ma para os núcleos de zircões reliquiares dos metaultramafitos (hornblenditos) do Passo do Belizário, do Complexo Encantadas. Nas porções de bordo dos zircões desta última unidade foram identificadas idades de $1989 \pm 21$ e $702 \pm 21$ $\mathrm{Ma}$, interpretadas como relacionadas aos eventos de metamorfismo regional $\mathrm{M}_{1}$ (fácies anfibolito) e $\mathrm{M}_{2}$ (fácies xistos verdes). Os autores ainda relacionam estes eventos metamórficos como manifestações respectivamente, das orogenias Encantadas e Camboriú, do ciclo Transamazônico e, a idade mais nova, como relacionada com a orogenia São Gabriel do ciclo Brasiliano.

Para os metagranitos equigranulares com textura milonítica foram obtidas idades pelo método $\mathrm{Rb}-\mathrm{Sr}$, de $507 \pm 38 \mathrm{Ma}$ e $524 \pm 17 \mathrm{Ma}$. Lenz et al. (2005) interpretam estes valores como indicativos de um evento de geração de trama metamórfica de baixo a médio grau metamórfico durante o Paleozóico Inferior no RS.

RELAÇÕES GEOLÓGICAS A relação estratigráfica discordante entre os metagranitos e o Gnaisse Encantadas foi observada nos levantamentos geológicos através de contatos intrusivos. Os gnaisses tonalíticos, trondhjemíticos e anfibolitos são as unidades dominantes e mais antigas. Estas unidades estão cortadas por corpos tabulares de metagranitos porfiríticos. Todas as unidades anteriores são cortadas por corpos tabulares de metagranitos equigranulares com espessuras centimétricas a métricas.

A estruturação geológica da área é caracterizada por dois eventos deformacionais de baixo ângulo denominados $\mathrm{D}_{1}$ e $\mathrm{D}_{2}$. O primeiro evento é responsável pela deformação dos corpos tonalíticos, trondjemíticos e dioríticos e pela geração de um bandamento milimétrico, regular e descontínuo originado pela segregação metamórfica $\left(\mathrm{Sb}_{1}\right)$ (Fig. $\left.4 \mathrm{a}\right)$. Este bandamento é de natureza composta, com corpos de tonalitos, trondjemíticos e anfibolíticos deformados e superpostos por um bandamento contínuo e relativamente regular de espessura milimétrica relacionado à segregação metamórfica (Philipp et al. 2008). Durante a evolução final deste evento alojam-se os corpos de granitos porfiríticos, e mais tardiamente, os metagranitos equigranulares. $\mathrm{O}$ segundo evento deformacional afeta o bandamento $\mathrm{Sb}_{1}$ dos gnaisses e os corpos de metagranitos originando dobras recumbentes $\left(\mathrm{F}_{2}\right)$ acompanhadas por uma foliação de superfície axial ( $\left.\mathrm{Sb}_{2}\right)$ (Fig. 4b). Um evento transcorrente $\mathrm{D}_{3}$ redobra as estruturas anteriores produzindo o padrão regional de dobramentos $\mathrm{F}_{3}$ aproximadamente normais e cilíndricos, direcionados segundo $\mathrm{N} 35-55^{\circ} \mathrm{E}$ e com superfície axial subvertical $\left(\mathrm{Sb}_{3}\right)$ (Fig. $4 \mathrm{c}$ ). Uma fase mais tardia redobra os eixos das dobras $\mathrm{F}_{3}$ e forma dobras assimétricas abertas a suaves com superficie axial marcada por uma clivagem de fratura orientada segundo $\mathrm{N} 20-40^{\circ} \mathrm{W}$ (Fig. 4d). A interação entre as últimas fases deformacionais resultou num padrão de interferência do tipo 1 de Ramsay (1967), gerando a estrutura dômica da região de Santana da Boa Vista (Machado et al. 1987).
Porcher \& Fernandes (1990) e Fernandes et al. (1992) interpretam a evolução estrutural do complexo e o desenvolvimento de zonas de cisalhamento de baixo ângulo e alto ângulo como simultâneos e relacionados ao escape tectônico promovido durante um evento de colisão continental.

Os metagranitóides estudados estão afetados por todas as fases de deformação que afetam o complexo, sugerindo uma evolução estrutural comum aos ortognaisses. As relações de corte observadas por vários autores são definidas pela discordância em baixo ângulo entre o bandamento $\mathrm{Sb}_{1}$ dos gnaisses e a disposição dos corpos tabulares de metagranitos. Esta relação tenderia a posicionar a colocação dos metagranitos como posterior a $\mathrm{D}_{1}$. Entretanto, os metagranitos afetados pelas dobras $\mathrm{F}_{2}$ apresentam uma foliação interna de natureza milonítica, sugerindo que já estavam sendo deformados anteriormente ao dobramento. As relações estruturais são sugestivas que o posicionamento dos metagranitos foi sincrônico ao evento $\mathrm{D}_{1} \mathrm{e}$, posteriormente, foram afetados pelo evento $\mathrm{D}_{2}$.

Os granitóides ocorrem dispostos de forma alongada ao longo da zona de contato entre o Complexo Encantadas e o Complexo Porongos. Esta estruturação posiciona os granitóides como sincrônicos com a zona de cisalhamento dúctil de baixo ângulo que define o contato entre a infra e a supra-estrutura da região.

Os metagranodioritos a monzogranitos porfiríticos constituem um corpo com forma alongada segundo a direção $\mathrm{N} 30^{\circ} \mathrm{E}$, envolvendo a área do domo ao longo do contato entre os complexos. Desdobrando as últimas fases deformacionais é possível supor que este granito cubra uma área com cerca de $70 \mathrm{~km}$ de extensão e entre 2 e $6 \mathrm{~km}$ de largura. A estrutura é foliada a bandada, com uma textura milonítica caracterizada por proporções entre 5 e $20 \%$ de porfiroclastos estirados de $\mathrm{K}$-feldspato envoltos em uma matriz fina com textura granoblástica nas porções quartzo-feldspáticas e lepidoblástica com orientação de biotita, associadas de modo subordinado com muscovita e clorita (Fig. 5a). Nos termos protomiloníticos a textura blastoporfirítica é definida por porfiroclastos prismáticos de K-feldspato de 1 a $5 \mathrm{~cm}$, envoltos por uma matriz de natureza milonítica com alto grau de recristalização. Não foram observadas relações diretas entre os metagranitóides porfiríticos e os ortognaisses, entretanto, a foliação principal dos metagranitóides é afetada pelas dobras recumbentes $\mathrm{F}_{2}$, sugerindo que a colocação destes corpos é anterior ao evento $\mathrm{D}_{2}$. Machado et al. (1987) descrevem contatos em baixo ângulo entre intrusões graníticas e os gnaisses tonalíticos.

As intrusões de metagranitos equigranulares mostram formas tabulares, em geral com espessuras entre 2 e 10 metros, rodeados por corpos menores, entre 5 e $20 \mathrm{~cm}$. Um corpo principal é identificado na porção leste do Domo de Santana, apresentando cerca de 10 $\mathrm{km}$ de extensão e 1 e $2 \mathrm{~km}$ de largura. Apesar de muito deformados identificam-se relações de corte de baixo ângulo com relação ao bandamento $\left(\mathrm{Sb}_{1}\right)$ dos gnaisses tonalíticos e trondhjemíticos. Na sua extremidade norte 

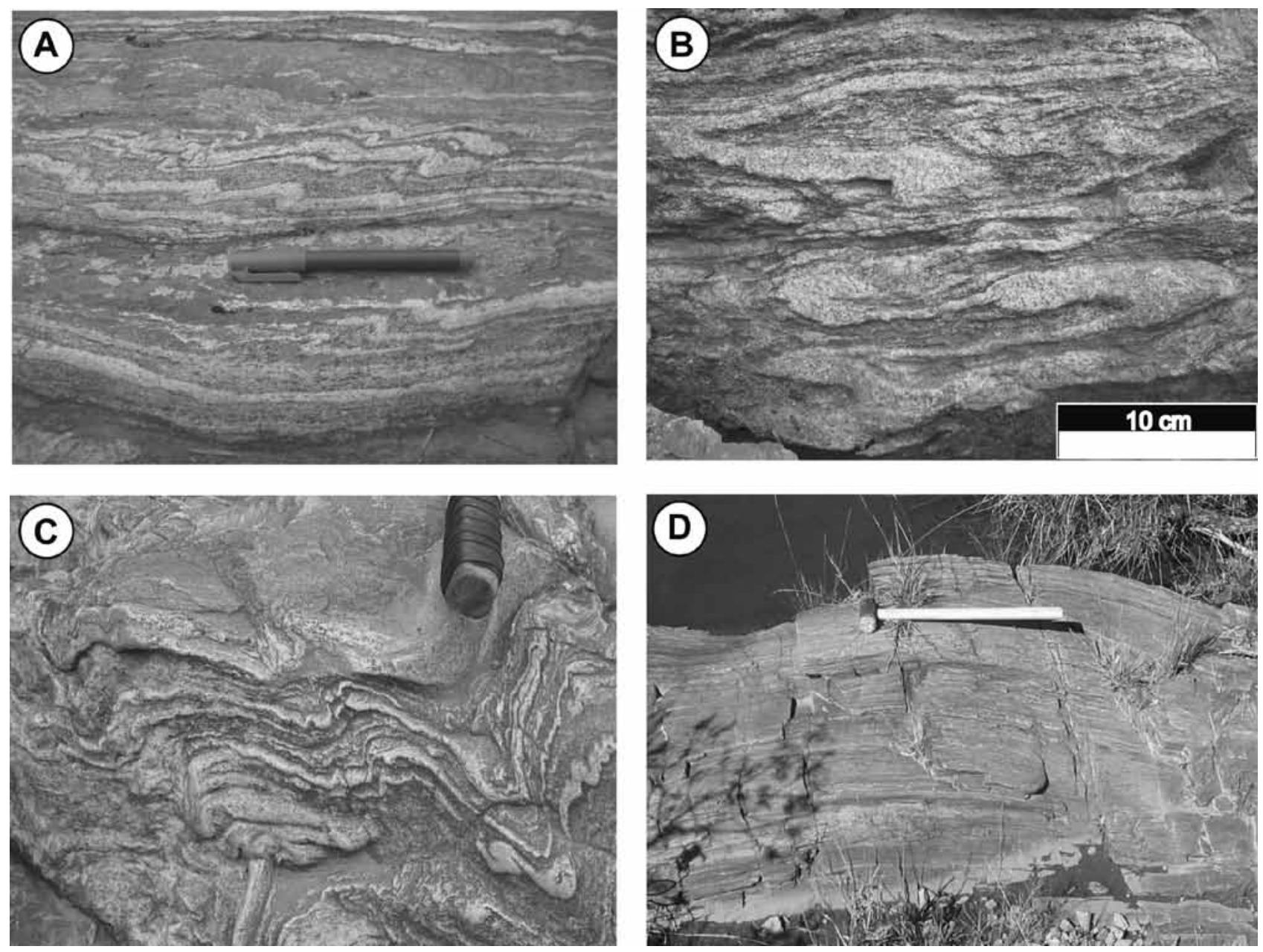

Figura 4 - Estruturas mesoscópicas das unidades do Complexo Encantadas. A) Bandamento composto caracterizado por injeções de metagranito equigranular em gnaisses tonalíticos com fino bandamento de segregação metamórfica; B) Dobras recumbentes $F_{2}$ afetando o bandamento dos gnaisses tonalíticos e as injeções de metagranitos equigranulares; C) Gnaisse tonalítico cortado por injeções de metagranito equigranular afetados por dobras $F_{3}$ suaves a abertas. D) Dobra aberta $F_{4}$ afetando a foliação milonítica e a lineação de estiramento do metagranito porfirítico, destacando a clivagem de fratura de superfície-axial $\left(S_{4}\right)$.

os metagranitos equigranulares cortam os metagranitos porfiríticos na forma de corpos tabulares com espessuras centimétricas. Assim como os metagranitos porfiríticos, os metagranitos equigranulares estão afetados pelas dobras $\mathrm{F}_{2}$, indicando que a colocação dos mesmos é anterior a $\mathrm{D}_{2}$ (Figs. $5 \mathrm{~b}$ e $5 \mathrm{c}$ ).

\section{PETROGRAFIA}

Metagranito Porfirítico Os metagranitos porfiríticos estão muito deformados, tem cor cinza escura a preta com pontos rosados a alaranjados definidos por porfiroclastos de K-feldspato. Apresenta estrutura foliada a bandada com augen de feldspatos envoltos por níveis milimétricos ricos em quartzo e plagioclásio e níveis máficos a base de biotita (Fig. 5c). A foliação é contínua e bem definida, comumente regular. Os níveis félsicos são compostos dominantemente por plagioclásio, K-feldspato e quartzo, com textura granoblástica interlobada inequigranular média $(0,2$ a $0,5 \mathrm{~mm})$ envolvendo subgrãos deformados de tamanhos variados dos mesmos minerais. Mostram proporções subordinadas de epidoto e mica branca fina crescendo sobre os feldspatos. Os níveis máficos são ricos em biotita, mostrando textura lepidoblástica média $(0,2$ a $0,8 \mathrm{~mm})$.

A composição é variável entre granodiorítica e monzogranítica (Fig. 6). Os principais minerais constituintes são K-feldspato, plagioclásio, quartzo e biotita tendo como acessórios comuns minerais opacos, alanita, apatita e zircão. $\mathrm{O}$ epidoto e a clorita são mais raros e se encontram principalmente preenchendo veios ou nas bordas e núcleos dos plagioclásios ou substituindo a biotita.

O K-feldspato é representado por Ortoclásio e ocorre como porfiroclastos de forma prismática pouco alongada a equidimensional, subédricos a estirados, envoltos por subgrãos e matriz milonítica, com dimensões entre 0.5 a $3 \mathrm{~cm}$, de cor rosa a laranja (Fig. 5d). As caudas de deformação mostram agregados granoblásticos interlobados a poligonais médios $(0.2-0.4 \mathrm{~mm})$ com novos grãos de microclínio metamórfico. O plagioclásio ocorre como porfiroclastos equidimensionais, zonados 

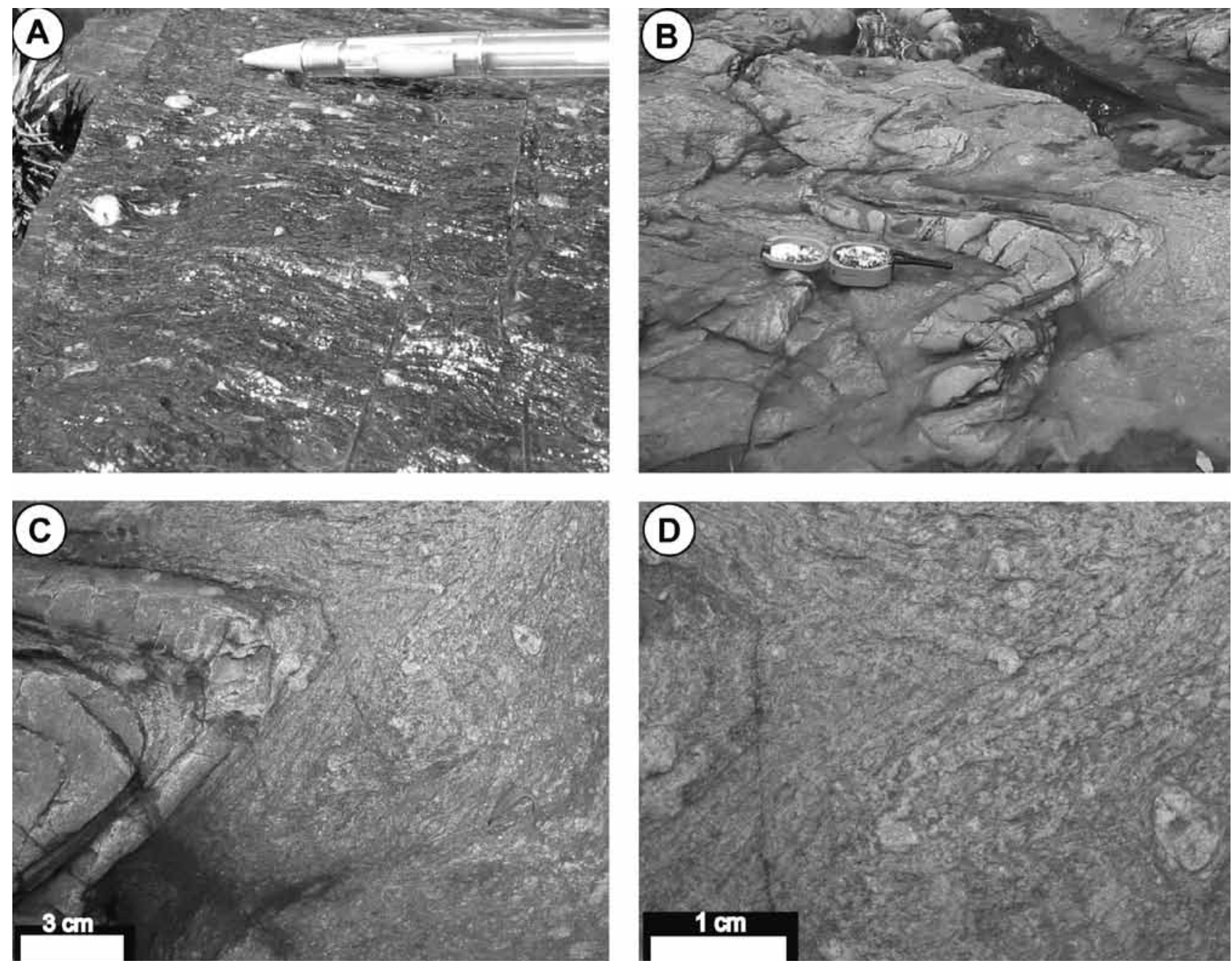

Figura 5 - Estruturas mesoscópicas do metagranito porfirítico. A) Bandamento milonítico definido por bandas quartzo-feldspáticas descontínuas e niveis dominantes de biotita envolvendo porfiroclastos de K-feldspato; $B$ ) Dobras recumbentes $F_{2}$ afetando a foliação milonítica dos metagranitos porfiríticos e injeções de metagranito equigranular; $C)$ Detalhe de zona de charneira de dobra $F_{2}$.destacando a foliação milonítica do metagranito porfiritico D) Detalhe da textura blastoporfiritica destacando porfiroclastos prismáticos de K-feldspato.

e com tamanhos entre 0,8 a $1,5 \mathrm{~mm}$. Mostram forte extinção ondulante, encurvamento de maclas e contatos suturados entre os grãos. Ao longo dos limites mostra a formação de novos grãos na matriz metamórfica de natureza milonítica, apresentando forma poligonal a equidimensional, limites retos a interlobados e tamanhos entre 0,2 a $0,3 \mathrm{~mm}$. O quartzo está dominantemente recristalizado, constituindo cristais de forma poligonal a equidimensional, subidioblásticos, variando de 0,2 a $0,5 \mathrm{~mm}$. Ocorrem raros porfiroclastos estirados, com forte extinção ondulante e tamanhos entre 0,5 e 2.5 $\mathrm{mm}$. A biotita é prismática, subidioblástica, com pleocroísmo variando de castanho esverdeado a castanho avermelhado. A presença da paragênese K-feldspato+ plagioclásio+quartzo+biotita caracteriza condições metamórficas mínimas da Fácies Anfibolito Médio.

Metagranitos Equigranulares Os metagranitos equigranulares tem cor rosa clara a alaranjada e apresentam uma estrutura foliada caracterizada pela orientação e estiramento de biotita, porfiroclastos de $\mathrm{K}$-feldspato e quartzo. Em zonas de alta deformação desenvolvem um bandamento incipiente com níveis milimétricos ricos em quartzo e K-feldspato e níveis máficos muito finos e descontínuos de biotita com textura lepidoblástica média (Fig. 7a). Estes níveis podem conter muscovita associada. Os níveis félsicos têm textura granoblástica interlobada a poligonal inequigranular média $(0,1 \mathrm{a} 0,3 \mathrm{~mm})$ e proporções variadas de porfiroclastos de K-feldspato e plagioclásio.

A composição é dominada por monzogranitos (Fig. 6). Os minerais principais são K-feldspato (microclínio) e quartzo, com pouco plagioclásio, biotita e muscovita, tendo como acessórios minerais opacos, allanita, zircão e apatita. A muscovita ocorre em zonas de alta deformação do granito associado a presença de fluidos aquosos.

$\mathrm{O} K$-feldspato é o microclínio e constitui porfiroclastos de forma prismática pouco alongada, subédrico a estirado, com dimensões entre 0.4 a $1.0 \mathrm{~cm}$ e 
cor rosa e laranja (Fig. 7b). Estão envoltos por subgrãos e matriz milonítica, parcialmente substituídos por mica branca. O plagioclásio ocorre como raros porfiroclastos equidimensionais, zonados e com tamanhos entre 0,3 a $1,0 \mathrm{~mm}$. Apresentam contatos suturados entre os grãos, com forte extinção ondulante e encurvamento de maclas. Ao longo dos limites mostra a formação de novos grãos metamórficos, com formas poligonal a equidimensional, limites retos a interlobados e tamanhos entre 0,1 a $0,3 \mathrm{~mm}$. O quartzo está dominantemente recristalizado, constituindo mosaicos de grãos poligonais subidioblásticos, variando de $0,1 \mathrm{a} 0,3 \mathrm{~mm}$. Ocorrem também porfiroclastos estirados, com forte extinção ondulante e tamanhos entre 0,5 e $2.5 \mathrm{~mm}$. A biotita tem forma prismática alongada, subidioblástica, com pleocroísmo castanho esverdeado a castanho avermelhado, variando de 0,3 a $0,8 \mathrm{~mm}$. Ocorre de modo intersticial nos níveis félsicos e como agregados nos níveis máficos. A muscovita é rara e ocorre principalmente na matriz metamórfica substituindo o K-feldspato. Também ocorre em termos de textura blastoequigranular grossa a pegmatítica como cristais hexagonais subédricos, de 1 a $5 \mathrm{~cm}$ e cor prata.

A paragênese K-feldspato + plagioclásio + quartzo + biotita também caracteriza condições metamórficas mínimas da fácies Anfibolito Médio.

GEOQUÍMICA Para a caracterização litogeoquímica dos metagranitos do Complexo Encantadas foram selecionadas e analisadas 24 amostras, sendo 09 do granito porfirítico e 15 do equigranular, para determinação da composição da rocha em termos de óxidos dos elementos maiores (\%) e dos elementos traços (ppm), incluindo elementos terras raras. Os resultados são apresentados nas tabelas 1 e 2 . As análises químicas foram realizadas no Activations Laboratories Ltda, Canadá e todos os elementos foram determinados por ICP-MS (Inductively Coupled Plasma-Mass Espectometry).

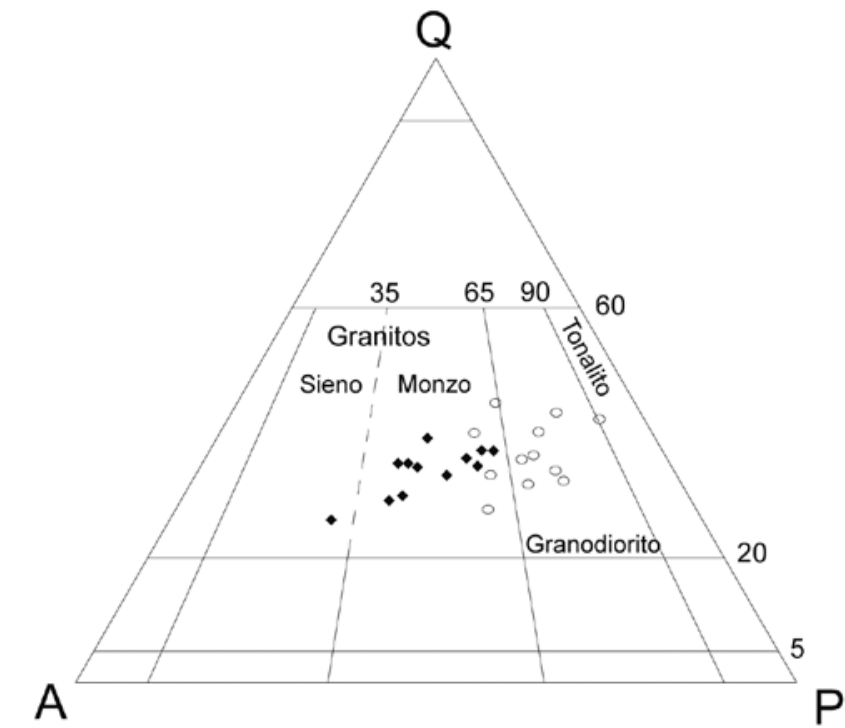

Metagranito Equigranular Metagranito Porfirítico

Figura 6 - Disposição das amostras dos metagranitos do Complexo Encantadas no diagrama QAP de Streckeisen (1976).

As análises químicas têm por objetivo caracterizar a composição e classificar os metagranitos do Complexo Encantadas. Adicionalmente investigou-se a partir da assinatura geoquímica, os principais processos de fracionamento, a geração e o provável ambiente geológico de formação dos protólitos.

Os óxidos dos elementos maiores foram representados em diagramas de Harker, tendo a $\mathrm{SiO}_{2}(\%)$ como índice de diferenciação. O conteúdo de $\mathrm{SiO}_{2}$ das amostras dos metagranitos porfiríticos varia de 67,15 $\%$ a $74,9 \%$, cobrindo um intervalo composicional de magmas ácidos caracterizado por granodioritos e mon-
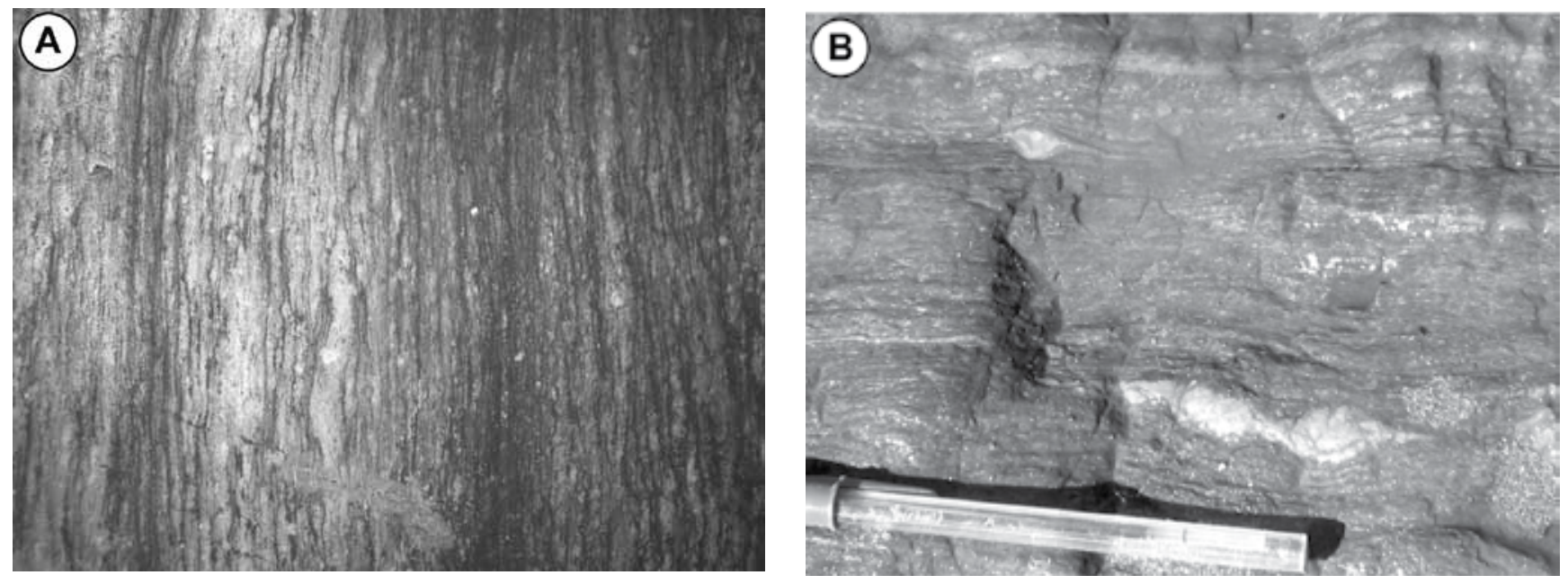

Figura 7 - Estruturas mesocópicas do metagranito equigranular. A) Bandamento milonítico, contínuo, regular e milimétrico (1-4 mm) destacando porfiroclastos de feldspatos envoltos por matriz fina; B) Detalhe de porfiroclastos de K-feldspato assimétricos indicando movimento lateral esquerdo ou de topo para a esquerda. 
Tabela 1 - Composição representativa dos elementos maiores (\% de peso) e traços (ppm) de amostras selecionadas dos metagranitos porfiriticos.

\begin{tabular}{|c|c|c|c|c|c|c|c|c|c|}
\hline Elem. & \begin{tabular}{|l} 
LR- \\
$14 \mathrm{~B}$ \\
\end{tabular} & $\begin{array}{l}\text { LR- } \\
17 \mathrm{~A}\end{array}$ & \begin{tabular}{|l} 
LR- \\
$19 A$ \\
\end{tabular} & LR-21 & LR-23 & LR-25 & \begin{tabular}{|l|} 
LR- \\
$27 \mathrm{~B}$ \\
\end{tabular} & \begin{tabular}{|l|l} 
LR- \\
29C \\
\end{tabular} & LR \\
\hline iO? & 7 & 6 & 6 & 74. & 4.86 & 73.33 & 68.98 & 68.96 & 67. \\
\hline $2 \mathrm{O} 3$ & 15.3 & 14.33 & 14.41 & 13.42 & 14.3 & 12.67 & 14.69 & 13.09 & 12. \\
\hline $2 \mathrm{O}$ & 1.82 & 3.02 & 5.53 & 94 & 1.3 & 4.48 & 2.93 & 6.32 & 6.6 \\
\hline $\mathrm{MnO}$ & 0.023 & 0.047 & 0.053 & 0.028 & 0.036 & 0.084 & 0.034 & 0.067 & 0.1 \\
\hline $\mathrm{MgO}$ & 0.58 & 0.88 & 1.81 & 0.57 & 0.39 & 0.41 & 0.96 & 1.05 & 0.8 \\
\hline $\mathrm{CaO}$ & .23 & 1.92 & 2.52 & 0.94 & 1.37 & 0.95 & 1.45 & 1.99 & 1.8 \\
\hline $\mathrm{Na} 2 \mathrm{O}$ & 3.83 & 3.78 & 3.45 & 3.33 & 4.17 & 3.16 & 3.37 & 3.17 & 3. \\
\hline $\mathrm{K} 2 \mathrm{O}$ & 4.9 & 4.11 & 2.69 & 4.46 & 3.66 & 3.91 & 4.73 & 3.29 & 3.8 \\
\hline $\mathrm{D} 2$ & 0.251 & 0.356 & 0.8 & 0.238 & 0.118 & 0.528 & \begin{tabular}{|l|l}
0.36 \\
\end{tabular} & 0.665 & 0.7 \\
\hline $\mathrm{O} 5$ & 0.09 & 0.14 & 0.33 & 0.08 & 0.07 & 0.13 & \begin{tabular}{|l|l}
0.11 \\
\end{tabular} & 0.18 & 0.2 \\
\hline OI & 4.21 & 0.69 & 0.96 & 0.7 & 0.68 & 1.09 & 1.11 & 0.69 & 0. \\
\hline Total & 100 & 98.3 & 99.73 & 100.6 & 100.9 & 100.7 & 98.71 & 99.46 & 70. \\
\hline $\mathrm{Ba}$ & 934 & 1157 & 1041 & 631 & 1049 & 2446 & 1359 & 2744 & 28 \\
\hline $\mathrm{Sr}$ & 306 & 356 & 510 & 198 & 434 & 51 & 398 & 362 & 34 \\
\hline $\mathrm{Y}$ & 14 & 18 & 27 & 14 & 7 & 61 & 14 & 28 & 24 \\
\hline $\mathrm{Zr}$ & 7 & 212 & 420 & 157 & 83 & 559 & 246 & 810 & 661 \\
\hline $\mathrm{Rb}$ & 136 & 126 & 83 & 131 & 67 & 46 & 90 & 57 & 56 \\
\hline $\mathrm{N}$ & 12 & 10 & 12 & 11 & 4 & 8 & 9 & 16 & 12 \\
\hline Cs & 1 & 1.2 & 1.8 & 0.7 & $<0.5$ & $<0.5$ & $<0.5$ & 0.9 & 0. \\
\hline $\mathrm{La}$ & 4.2 & 86.9 & 145 & 4.2 & 24.8 & 212 & \begin{tabular}{|l|}
69.3 \\
\end{tabular} & 35.9 & 68 \\
\hline $\mathrm{Ce}$ & 3 & 160 & 332 & .9 & 47.3 & 13 & 137 & 73.8 & 14 \\
\hline $\operatorname{Pr}$ & .6 & 18.3 & 33.8 & 0.1 & 5.11 & 39.3 & 15.2 & 9.59 & 16 \\
\hline N & 8 & 54.7 & 110 & .7 & +.1 & 64 & 45.2 & 34.8 & \\
\hline $\mathrm{Sm}$ & 5.2 & 8.4 & 16.1 & 5.5 & 2.3 & 16.7 & 7 & 7.2 & 8.8 \\
\hline 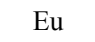 & 17 & 1.02 & 3.21 & . & 0.00 & 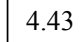 & 1.11 & 4.29 & . \\
\hline $\mathrm{Gd}$ & 3.5 & 6 & 9.6 & 4.1 & 1.7 & 13.5 & 4.7 & 6.5 & 6.7 \\
\hline $\mathrm{Tb}$ & 0.5 & 08 & 1 & 0.5 & 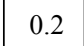 & 1.7 & 0.6 & 1 & 0 \\
\hline Dy & 2.4 & 3.6 & 5. & 2.5 & 1.3 & 8. & 2.8 & 5 & 4.4 \\
\hline 110 & 0.5 & 0 & 1.1 & 0.4 & 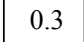 & 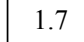 & 0.5 & 1 & 00 \\
\hline LI & 1.0 & 1.9 & 2.9 & 1 & 0.0 & 4.7 & 1.4 & 3 & 2. \\
\hline $\mathrm{Tm}$ & 23 & 0.26 & 038 & 0 & 11 & .63 & 0.19 & 0.46 & 0 \\
\hline Y & 1.6 & - & 00 & 1.1 & 0.9 & .0 & 1.2 & 3.2 & 2.2 \\
\hline $\mathrm{Lu}$ & 0.24 & 0.2 & 0.32 & 0.16 & 0.13 & 0.54 & 0.15 & 0.51 & 0. \\
\hline $\mathrm{Hf}$ & 4.4 & 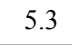 & 9.9 & 4.1 & 2.2 & 11.6 & 6.2 & 16.5 & 12 \\
\hline Ta & 0.9 & 0.9 & 0 & 0 & & 0 & 0.7 & 1.3 & 0.9 \\
\hline Th & 3.8 & 17.9 & 15.1 & 18.9 & 0.0 & .0 & 23.1 & 4.7 & 7.1 \\
\hline $\mathrm{U}$ & 2.3 & 1.4 & 0.8 & 1.7 & 0.8 & 0.5 & 0.6 & 2.2 & 1.7 \\
\hline
\end{tabular}

zogranitos. Os teores de $\mathrm{Al}_{2} \mathrm{O}_{3}$ são elevados, com valores entre 15,3 e $12,6 \%$. Os teores de $\mathrm{Fe}_{2} \mathrm{O}_{3}$ (total) são moderados, variando de 6,6 a $1,3 \%$, com teores mais baixos de $\mathrm{MgO}$, variando de 1,8 a $0,3 \%$ e de $\mathrm{TiO}_{2}$, entre 0,1 a $0,8 \%$. Os metagranitos equigranulares são mais
Tabela 2 - Composição representativa dos elementos maiores (\% de peso) e traços (ppm) de amostras selecionadas dos metagranitos equigranulares.

\begin{tabular}{|c|c|c|c|c|c|c|c|c|c|c|c|}
\hline & \begin{tabular}{|l} 
LR- \\
2C
\end{tabular} & $\begin{array}{c}\text { LR- } \\
7 \mathrm{~B} \\
\end{array}$ & LR-9 & \begin{tabular}{|c|} 
LR- \\
$11 \mathrm{~d}$ \\
\end{tabular} & $\begin{array}{l}\text { LR- } \\
11 \mathrm{C}\end{array}$ & \begin{tabular}{|l|} 
LR- \\
$11 \mathrm{E}$ \\
\end{tabular} & \begin{tabular}{|l} 
LR- \\
13B \\
\end{tabular} & $\begin{array}{l}\text { LR- } \\
17 \mathrm{~B}\end{array}$ & $\begin{array}{c}\text { LR- } \\
24\end{array}$ & $\begin{array}{c}\text { LR- } \\
26\end{array}$ & \begin{tabular}{|l} 
LR- \\
$29 \mathrm{a}$ \\
\end{tabular} \\
\hline $\mathrm{SiO} 2$ & 77.38 & 76.3 & 74.76 & 69.75 & 73.67 & 74.03 & 72.6 & 75.65 & 73.02 & 70.43 & 72.37 \\
\hline $\mathrm{Al} 2 \mathrm{O} 3$ & 13.17 & 13.72 & 12.83 & 15.44 & 13.21 & 13.9 & 14.55 & 13.78 & 14.84 & 14.49 & 13.36 \\
\hline $\mathrm{Fe} 2 \mathrm{O} 3 \mathrm{t}$ & 0.58 & 0.47 & 1.05 & 2.2 & 0.94 & 1.16 & 0.78 & 0.37 & 1.59 & 2.62 & 1.68 \\
\hline $\mathrm{MnO}$ & 0.004 & 0.004 & 0.011 & 0.038 & 0.013 & 0.019 & 0.013 & 0.041 & 0.032 & 0.019 & 0.019 \\
\hline $\mathrm{MgO}$ & 0.04 & 0.11 & 0.27 & 0.87 & 0.23 & 0.2 & 0.14 & 0.05 & 0.43 & 0.78 & 0.58 \\
\hline $\mathrm{CaO}$ & 0.65 & 1.01 & 0.65 & 2.09 & 1.84 & 0.91 & 0.86 & 0.4 & 1.7 & 1.16 & 0.67 \\
\hline $\mathrm{Na} 2 \mathrm{O}$ & 4.12 & 4.67 & 2.86 & 4.27 & 3.08 & 2.96 & 2.14 & 3.17 & 4.58 & 3.04 & 2.9 \\
\hline $\mathrm{K} 2 \mathrm{O}$ & 4.63 & 3.14 & 5.3 & 3.32 & 4.64 & 6.8 & 8.68 & 7.15 & 3.05 & 5.59 & 6 \\
\hline $\mathrm{TiO} 2$ & 0.05 & 0.027 & 0.082 & 0.249 & 0.084 & 0.076 & 0.032 & 0.01 & 0.157 & 0.195 & 0.187 \\
\hline $\mathrm{P} 2 \mathrm{O} 5$ & 0.02 & 0.03 & 0.03 & 0.15 & 0.04 & \begin{tabular}{|l|}
0.04 \\
\end{tabular} & \begin{tabular}{|l|l}
0.09 \\
\end{tabular} & 0.02 & 0.08 & 0.13 & 0.08 \\
\hline LOI & 0.32 & 0.42 & 0.74 & 1.33 & 0.5 & 0.69 & 0.4 & 0.29 & 0.85 & 0.89 & 0.76 \\
\hline Total & 101 & 99.89 & 98.61 & 99.71 & 98.24 & 100.8 & 100.3 & 100.9 & 100.3 & 99.35 & 98.62 \\
\hline V & 6 & 8 & 7 & 22 & 8 & 14 & 9 & 6 & 14 & 16 & 16 \\
\hline $\mathrm{Ba}$ & 55 & 652 & 6343 & 1828 & 2184 & 2567 & 3601 & 1097 & 1006 & 1624 & 954 \\
\hline $\mathrm{Sr}$ & 39 & 302 & 514 & 683 & 644 & 458 & 452 & 214 & 541 & 408 & 257 \\
\hline $\mathrm{Y}$ & 8 & $<2$ & 2 & 4 & $<2$ & 6 & 10 & 24 & 2 & 10 & 8 \\
\hline $\mathrm{Zr}$ & 94 & 54 & 100 & 109 & 92 & 149 & 60 & 49 & 90 & 152 & 154 \\
\hline $\mathrm{Rb}$ & 143 & 35 & 40 & 70 & 70 & 107 & 92 & 194 & 42 & 112 & 78 \\
\hline $\mathrm{Nb}$ & 5 & $<1$ & 1 & 2 & $<1$ & 1 & $<1$ & 27 & 3 & 4 & 4 \\
\hline Cs & $<0.5$ & $<0.5$ & 0.9 & 0.7 & $<0.5$ & $<0.5$ & $<0.5$ & $<<0.5$ & $<0.5$ & 0.7 & $<0.5$ \\
\hline $\mathrm{La}$ & 4.8 & 12.4 & 48 & 92.8 & 16.1 & 33.6 & 179 & 7.7 & 26.9 & 52.4 & 48.8 \\
\hline $\mathrm{Ce}$ & 9.1 & 24 & 92.5 & 164 & 32.7 & 80.6 & 323 & 21 & 48.4 & 89 & 93.6 \\
\hline $\operatorname{Pr}$ & 1.42 & 2.59 & 9.86 & 16.8 & 3.52 & 7.84 & 31.1 & 2.93 & 5.02 & 10.5 & $\mid 10.1$ \\
\hline $\mathrm{Nd}$ & 6.7 & 8 & 27.7 & 46.8 & 11.3 & 23.5 & 81.1 & 13.1 & 14.4 & 29.5 & 29.3 \\
\hline $\mathrm{Sm}$ & 1.7 & 1.2 & 3.5 & 5.1 & 1.9 & 3.9 & 9.6 & 3.3 & 2 & 4.5 & 4.7 \\
\hline $\mathrm{Eu}$ & 0.22 & 0.77 & 1.35 & 1.25 & 0.94 & 1.14 & 1.41 & 0.25 & 0.78 & 0.9 & 0.7 \\
\hline $\mathrm{Gd}$ & 1.8 & 0.8 & 1.8 & 2.5 & 1.1 & 2.4 & 5.2 & 2.7 & 1.3 & 3.1 & 3 \\
\hline $\mathrm{Tb}$ & 0.3 & $<0.1$ & 0.2 & 0.2 & 0.1 & 0.3 & 0.6 & 0.5 & 0.1 & 0.4 & 0.4 \\
\hline Dy & 1.8 & 0.4 & 0.7 & 0.9 & 0.4 & 1.4 & 2.4 & 3 & 0.6 & 1.8 & 1.6 \\
\hline Ho & 0.4 & $<0.1$ & 0.1 & 0.2 & $<0.1$ & 0.3 & 0.4 & 0.5 & $<0.1$ & 0.4 & 0.3 \\
\hline Er & 1.2 & 0.2 & 0.3 & 0.5 & 0.2 & 0.8 & 1.1 & 1.6 & 0.3 & 1.1 & 0.8 \\
\hline $\mathrm{Tm}$ & 0.18 & $<0.05$ & $<0.05$ & $<0.05$ & $<0.05$ & 0.1 & 0.15 & 0.28 & $<0.05$ & 0.14 & 0.11 \\
\hline $\mathrm{Yb}$ & 1.2 & 0.1 & 0.3 & 0.4 & 0.2 & 0.7 & 0.9 & 1.9 & 0.2 & 0.9 & 0.7 \\
\hline $\mathrm{Lu}$ & 0.17 & $<0.04$ & 0.05 & 0.05 & $<0.04$ & 0.1 & 0.12 & 0.26 & $<0.04$ & 0.13 & 0.11 \\
\hline Hf & 3.9 & 2 & 2.6 & 2.4 & 2.7 & 4.1 & 1.5 & 8 & 2.1 & 3.7 & 4.3 \\
\hline $\mathrm{Ta}$ & $<0.1$ & 0.1 & 0.2 & 0.1 & $<0.1$ & 0.1 & 0.1 & 4.4 & 0.1 & 0.3 & 0.2 \\
\hline Th & 29.9 & 4.5 & 5.9 & 14.1 & 2.8 & 13.7 & 43.9 & 11.9 & 3.2 & 29 & 24.5 \\
\hline U & 1.5 & 1.5 & 0.4 & 0.3 & 0.2 & 0.5 & 0.8 & 8 & 0.4 & 1.5 & 2.3 \\
\hline
\end{tabular}

silicosos, com conteúdo de $\mathrm{SiO}_{2}$ variando entre $69,7 \%$ e 77,4 \%, caracterizando um magma ácido com composição variando entre sienogranitos e monzogranitos. Os teores de $\mathrm{Al}_{2} \mathrm{O}_{3}$ são elevados e variam entre 15,4 e 12,8 $\%$. Os teores de $\mathrm{Fe}_{2} \mathrm{O}_{3}$ (total) são baixos, variando de 
2,2 a $0,6 \%$, com teores ainda mais baixos de $\mathrm{MgO}$, variando de 0,8 a $0,04 \%$ e de $\mathrm{TiO}_{2}$, entre 0,195 a $0,01 \%$.

As disposições dos elementos maiores dos metagranitos nos diagramas de Harker definem alinhamentos lineares para a maioria dos elementos. Os dois metagranitos estudados definem alinhamentos distintos, embora subparalelos, sendo mais bem definidos para os granitos equigranulares. Com o aumento progressivo do teor de $\mathrm{SiO}_{2}$ observa-se um decréscimo regular nos teores de $\mathrm{TiO}_{2}, \mathrm{MgO}, \mathrm{FeO}, \mathrm{CaO}, \mathrm{Al}_{2} \mathrm{O}_{3}$ e $\mathrm{P}_{2} \mathrm{O}_{5}$ (Fig. 8). Os teores de $\mathrm{Na}_{2} \mathrm{O}$ mostram tendência de enriquecimento com a diferenciação, apesar de apresentarem uma dispersão dos pontos. Os granitos mostram comportamento distinto com relação ao $\mathrm{K}_{2} \mathrm{O}$. Os termos porfiríticos apresentam aumento relativo até cerca de $71 \%$ de $\mathrm{SiO}_{2}$, quando invertem o comportamento. Os metagranitos equigranluares mostram um empobrecimento contínuo com relação ao aumento do teor de $\mathrm{SiO}_{2}$. A tendência observada nos elementos maiores sugere que as amostras selecionadas são cogenéticas e representam a evolução de duas unidades magmáticas distintas. Os alinhamentos observados sugerem a atuação de processos de cristalização fracionada, com provável fracionamento de plagioclásio, biotita, K-feldspato e apatita.

Os metagranitos estudados mostram teores elevados e variáveis de elementos litófilos de grande raio iônico (LILE) como $\mathrm{Rb}, \mathrm{Ba}, \mathrm{Sr}$ e Ce. Os teores de elementos de alto potencial iônico (HFSE) como o $\mathrm{Nb}, \mathrm{Zr}$ e Y são moderados a baixos.

Os teores de $\mathrm{Rb}$ são moderados e o comportamento deste elemento se caracteriza por uma distribuição pouco regular, com grande dispersão dos dados (Fig. 9a). O decréscimo de $\mathrm{Rb}$ pode ser indicativo do fracionamento de biotita, que é a fase mineral com $\mathrm{Kd}$ mais compatível (Hanson 1978; Mahood \& Hildreth 1983; Watson \& Harrison 1983). Entretanto, variações tão extremas para amostras com um mesmo teor em $\mathrm{SiO}_{2}$ devem ser causadas pela atuação de processos metamórficos. Como na tendência geral são rochas miloníticas, o elevado grau de recristalização da biotita ígnea e de K-feldspato pode ter afetado o teor original de $\mathrm{Rb}$. A remobilização destes elementos é atribuída a circulação de fluídos metamórficos (Yardley 1989).

Os teores de Ba são em geral muito elevados, e mostram uma distribuição relativamente regular definindo tendências de empobrecimento com a diferenciação. Os termos equigranulares mostram uma tendência definida relação a diferenciação, sugerindo o fracionamento de K-feldspato e/ou biotita no período inicial de diferenciação desta unidade magmática (Fig. 9b).

Os teores de $\mathrm{Sr}$ são elevados para rochas granitóides de afinidade cálcico-alcalina, mostrando uma tendência ao empobrecimento com o aumento do teor de $\mathrm{SiO}_{2}$, embora com grande dispersão para os termos equigranulares (Fig. 9c). O decréscimo de $\mathrm{Sr}$ pode ser indicativo do fracionamento de plagioclásio e/ou biotita.

O granito porfirítico possui teores mais elevados de $\mathrm{Zr}$, entretanto, nos dois metagranitos os teores de $\mathrm{Zr}$ diminuem com o aumento do teor de sílica, indicando o fracionamento precoce de zircão (Fig. 9d).
Série Magmática A representação dos dados dos metagranitos do Complexo Encantadas no diagrama de álcalisílica total (TAS) (Middlemost 1994) confirma a composição granodiorítica a granítica para os termos porfiríticos para os termos equigranulares (Fig. 10). A análise das relações alumina/cálcio-álcalis demonstra que os metagranitos são de natureza levemente peraluminosa (Fig. 11).

A disposição das amostras no diagrama AFM (Kuno 1968) e aprimorado por Irvine e Baragar (1971), caracteriza os metagranitos como da série cálcico-alcalina (Fig. 12). A confirmação da afinidade cálcico-alcalina também pode ser observada no diagrama de Jensen (1976) (Fig. 13). A disposição das amostras no diagrama $\mathrm{K}_{2} \mathrm{O}$ vs $\mathrm{SiO}_{2}$ (Le Maitre et al. 1989) caracteriza os metagranitos do Complexo Encantadas como pertencentes a série cálcico-alcalina de médio a alto $\mathrm{K}$ (Fig. 14). Algumas amostras têm teores de $\mathrm{K}_{2} \mathrm{O}$ e $\mathrm{Ba}$ muito elevados compatíveis com rochas da série shoshonítica. Esta característica pode também representar uma limitação na homogeneização da amostra em função das rochas serem finamente bandadas e fortemente deformadas.

Elementos Terras Raras Os padrões de elementos terras raras normalizado por valores condríticos (Sun 1982) dos metagranitos mostraram um padrão similar, caracterizando um conjunto homogêneo de unidades magmáticas (Fig. 15a,b). Os dois granitos mostram padrões muito semelhantes, entretanto, os termos equigranulares mostram maior variação composicional. As amostras mostram um padrão enriquecido em elementos terras raras leves em relação aos elementos terras raras pesados. Os metagranitos mostram padrões comuns para rochas cálcico-alcalinas, com forte enriquecimento de ETRL e empobrecimento de ETRP, sugerindo uma participação crustal no processo de formação dos magmas ácidos. As anomalias do Eu são negativas e moderadas com algumas poucas amostras apresentando anomalias positivas, sugerindo a segregação e concentração localizada de plagioclásio.

Diagramas Multi-elementares Os padrões obtidos nos diagramas multielementares normalizados pelos valores do MORB para os metagranitos do Complexo Encantadas mostram-se muito similares (Fig. 16a,b). Os metagranitos têm teores em geral elevados para elementos do tipo LILE e elementos terras raras leves. As principais diferenças estão relacionadas aos teores ligeiramente mais elevados de LILE como $\mathrm{Rb}, \mathrm{Ba}, \mathrm{U}$, Th e $\mathrm{K}$, as anomalias mais negativas de $\mathrm{Nb}$ e Ti e os teores mais baixos de ETR pesadas do metagranito equigranular em comparação como porfirítico. Estas variações, principalmente de $\mathrm{Rb}, \mathrm{Ba}$ e $\mathrm{Sr}$ podem estar relacionadas a transformação metamórfica desta unidade, que é controlada pela ação de fluídos aquosos e pela recristalização avançada do K-feldspato. As anomalias de Th e Ba indicam a participação crustal no processo de geração dos magmas, enquanto que as anomalias negativas de $\mathrm{Nb}$ com relação ao La e a razão Ti/Gd sugerem que a geração dos magmas ocorreu a partir de fontes 

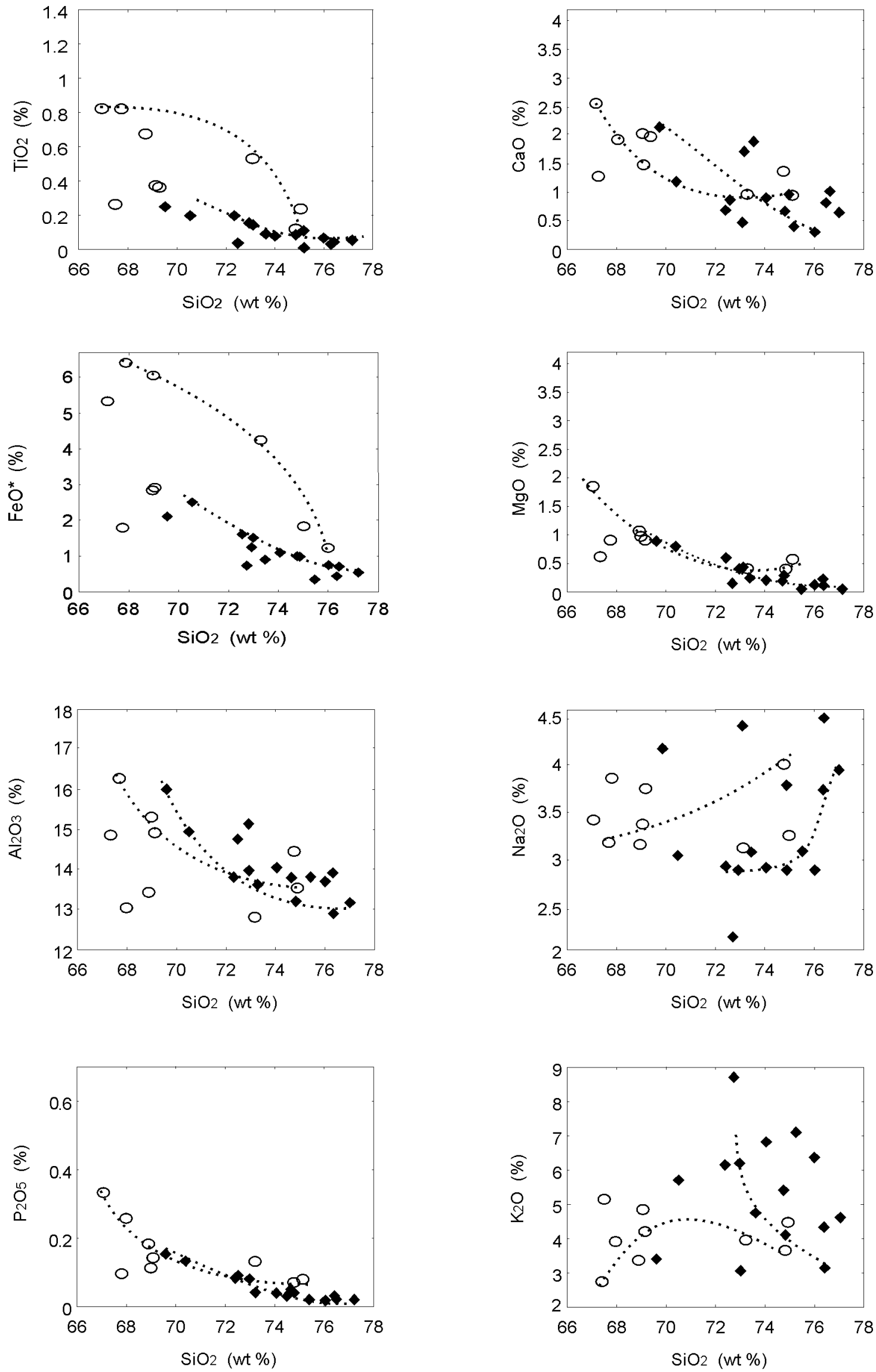

- Metagranito Equigranular

Metagranito Porfirítico

Figura 8 - Diagramas de Harker com variação dos elementos maiores para os metagranitos do Complexo Encantadas. 
Geoquímica e petrologia dos metagranitos do Complexo Encantadas, Santana da Boa Vista, (RS): a evolução de uma margem continental ativa no Paleoproterozóico
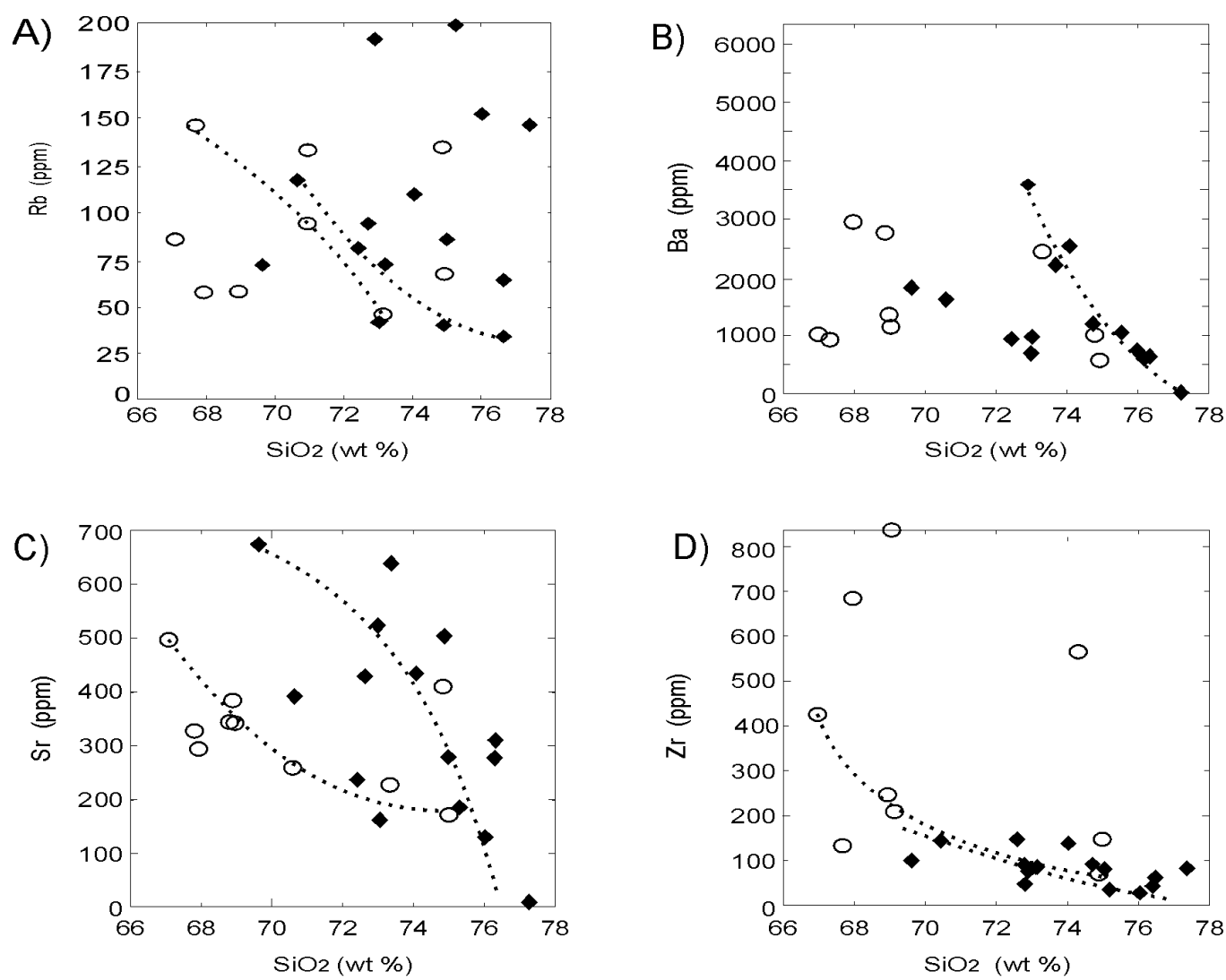

- Metagranito Equigranular

Metagranito Porfirítico

Figura 9 - Diagramas de variação de $\mathrm{Rb}, \mathrm{Ba}$, $\mathrm{Sr}$ e $\mathrm{Zr}$ (ppm) versus $\mathrm{SiO}_{2}$ para os metagranitos do Complexo Encantadas.

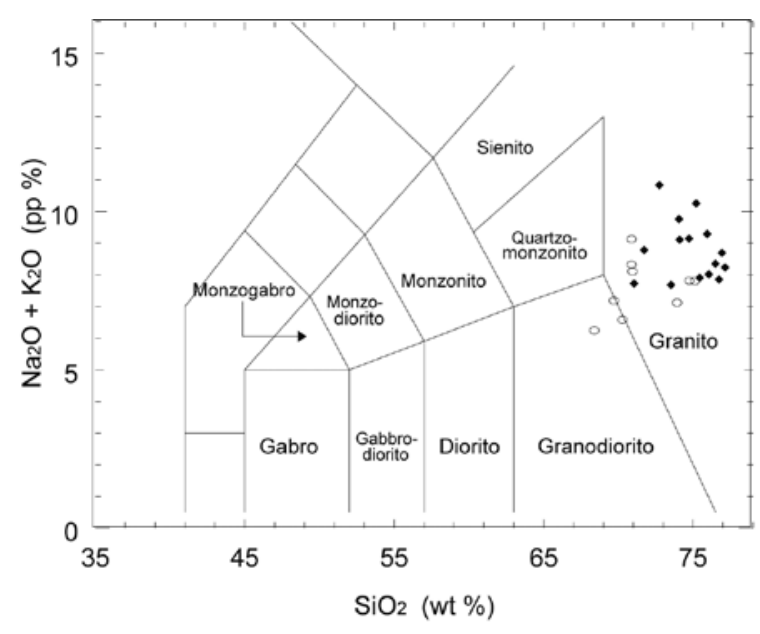

Metagranito Equigranular $\bigcirc$ Metagranito Porfirítico

Figura 10 - Diagrama álcalis total versus sílica (TAS) para os metagranitos do Complexo Encantadas.

mantélicas modificadas um evento de subducção precedente. A presença de baixas razões $\mathrm{La} / \mathrm{Nb}$ em todas as litologias dos metagranitos é uma feição sugestiva de magmatismo gerado em zonas de subducção ou a partir

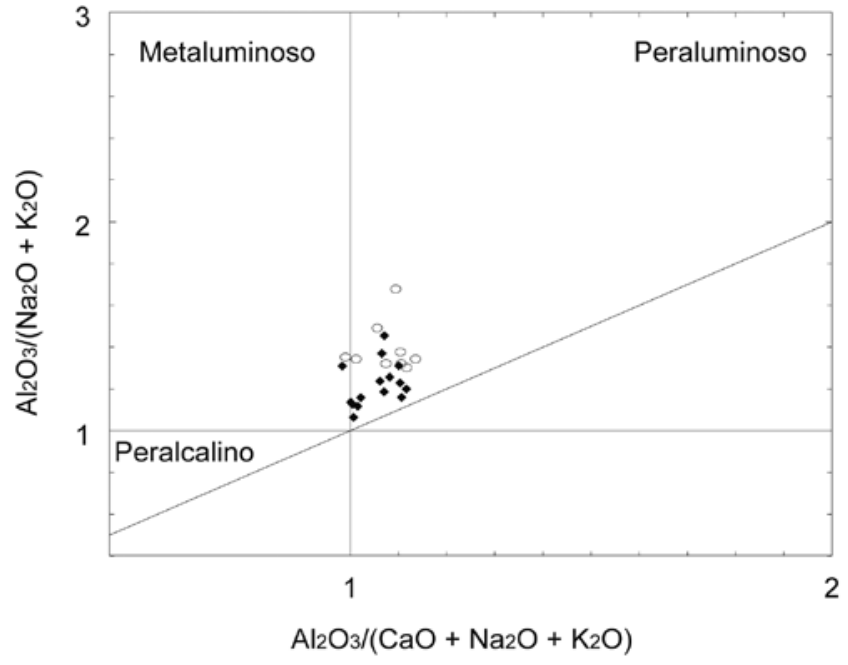

- Metagranito Equigranular $\bigcirc$ Metagranito Porfirítico

Figura 11 - Diagrama de Shand para avaliação das relações entre álcalis e alumina dos metagranitos estudados segundo Maniar \& Piccoli (1989).

de protólitos com esta característica como indicado por Thompson et al. (1984). 


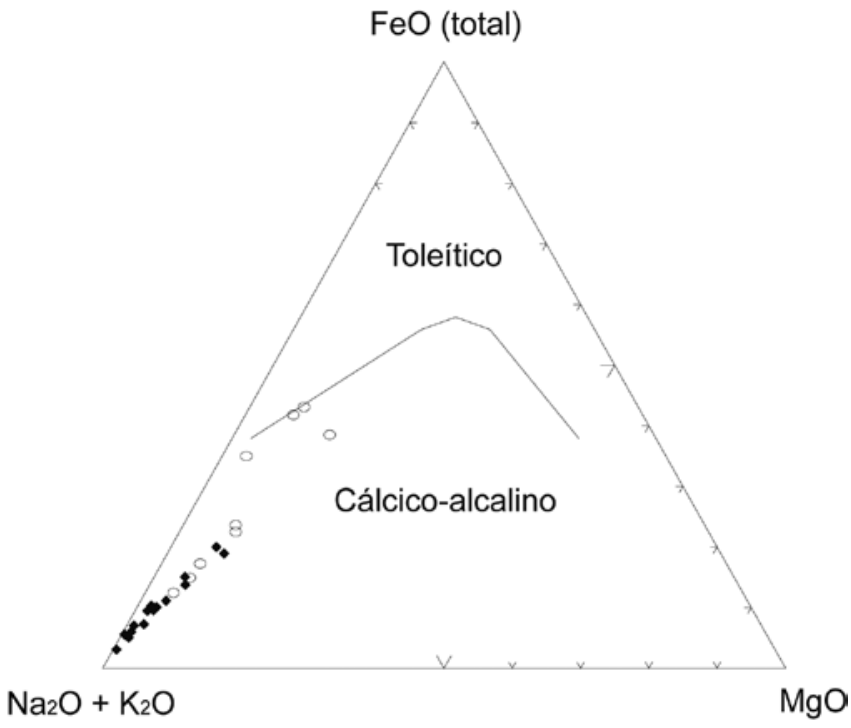

Metagranito Equigranular $\bigcirc$ Metagranito Porfiritico

Figura 12 - Disposição dos metagranitos no diagrama AFM de Irvine \& Baragar (1971).

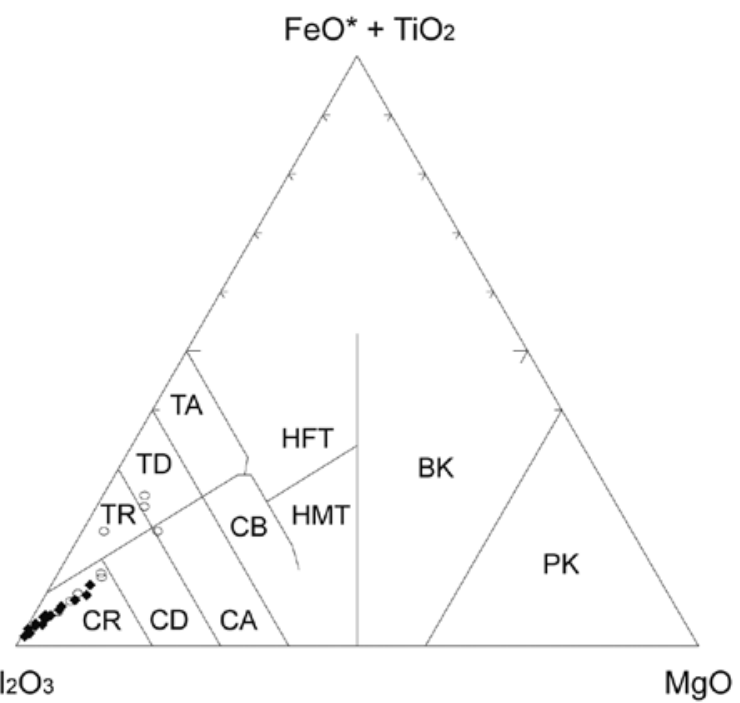

$\mathrm{Al}_{2} \mathrm{O}_{3}$ $\mathrm{MgO}$

- Metagranito Equigranular $\bigcirc$ Metagranito Porfirítico

Figura 13 - Disposição dos metagranitos no diagrama de Jensen (1976).

Ambiente Geotectônico Para a determinação do ambiente geotectônico de geração dos metagranitos do complexo, foram utilizados os diagramas de discriminação de Pearce et al. (1984) e Pearce (1996). A representação dos dados no diagrama $\mathrm{Nb} v s \mathrm{Y}$ formam uma tendência linear definida no campo dos granitos de arco vulcânico e granitos sin-colisionais (Fig. 17a). No diagrama $\mathrm{Rb}$ vs $(\mathrm{Y}+\mathrm{Nb})$ as amostras dos metagranitos dispõe-se no campo dos granitos de arco vulcânico (Fig. 17b).

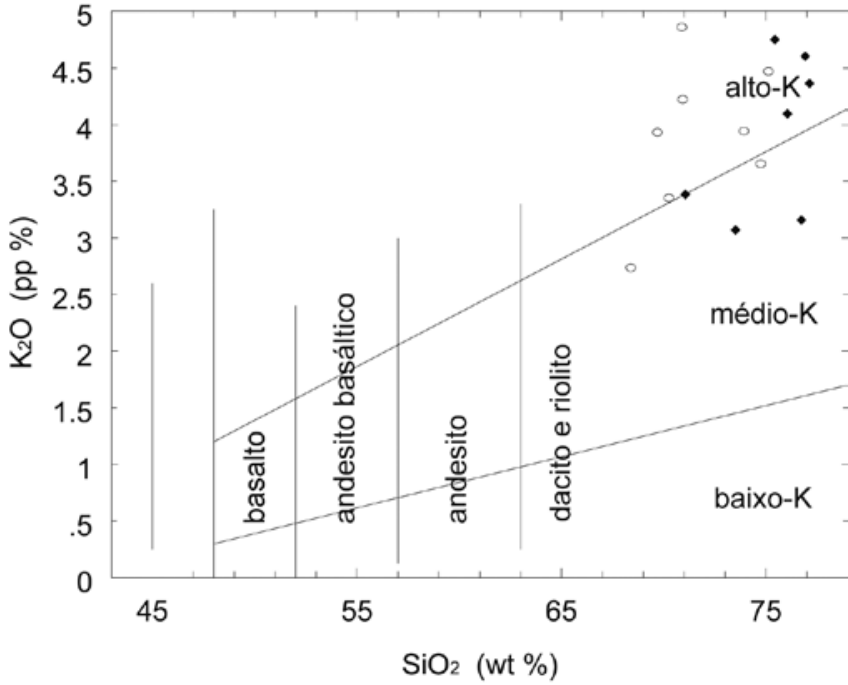

- Metaleucogranito Metagranito Porfirítico

Figura 14 - Diagrama $\mathrm{K}_{2} \mathrm{O}$ com relação a $\mathrm{SiO}_{2}$ (Le Maitre 1989) para classificação das rochas cálcico-alcalinas.

A)

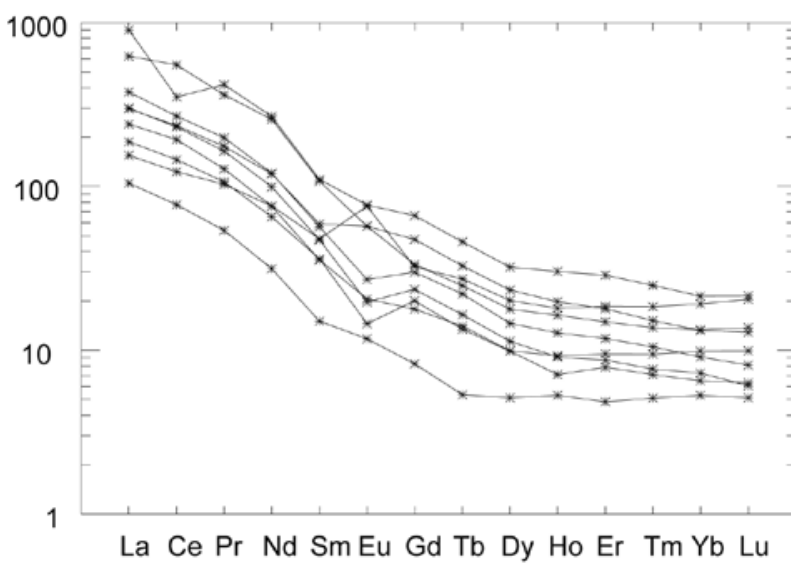

B)

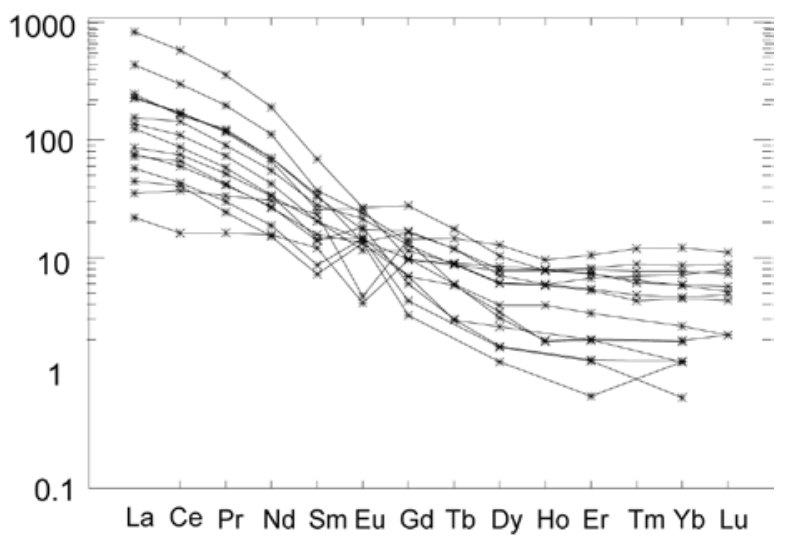

Figura 15 - Abundância dos ETR dos metagranitos porfiríticos (a) e equigranulares (b) do Complexo Encantadas normalizados pelo condrito (Sun 1982). 
A)

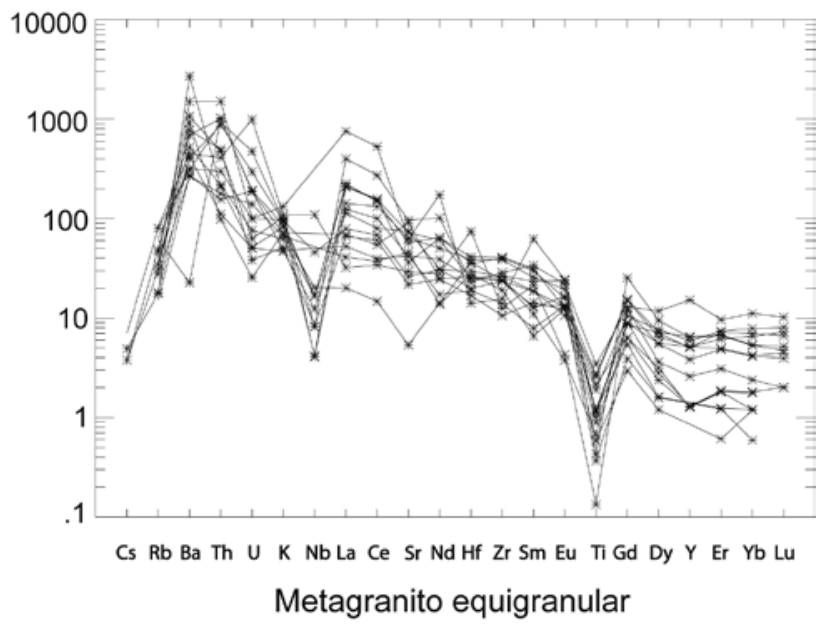

B)

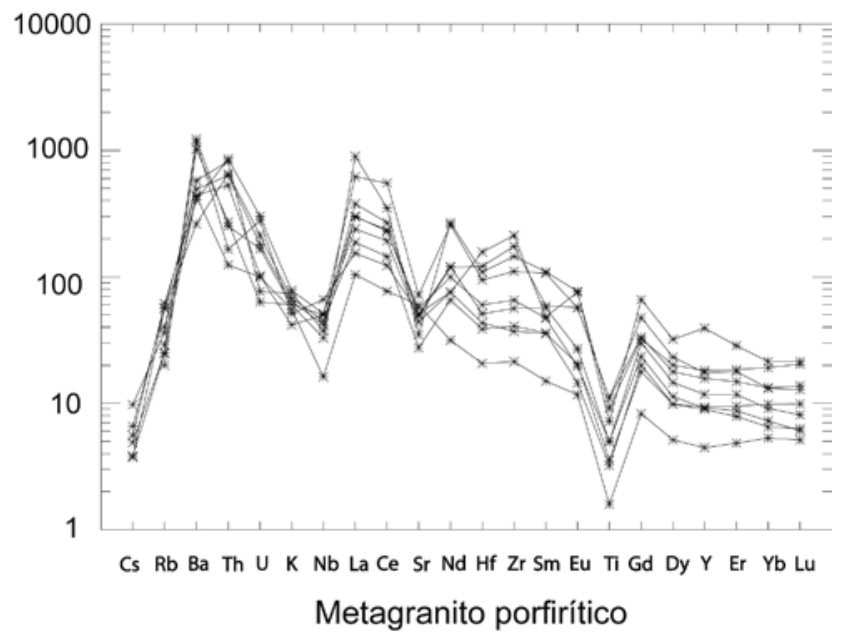

Figura 16 - Diagramas multielementares contendo elementos traços normalizados pelo condrito (Sun 1982) para os metagranitos estudados.

A)

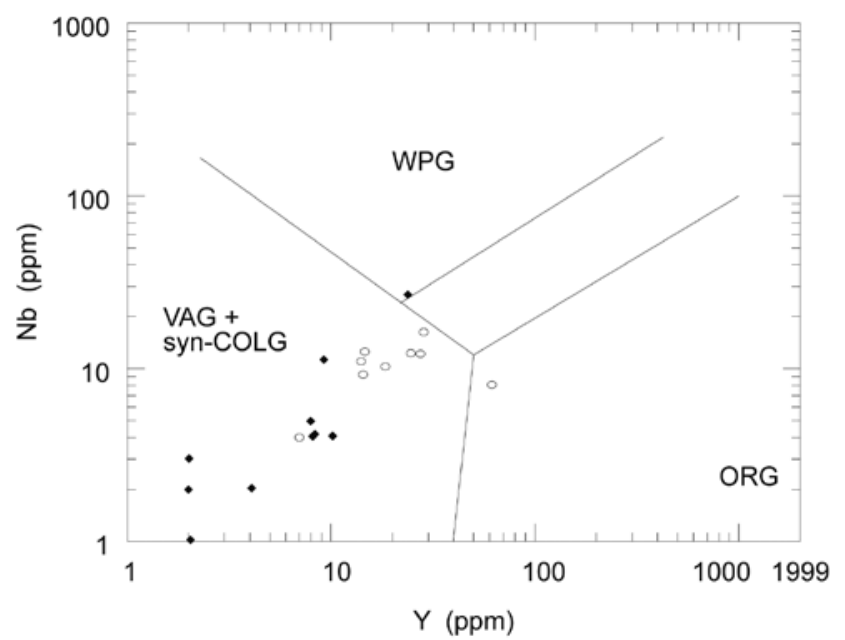

Metagranito Porfirítico
B)

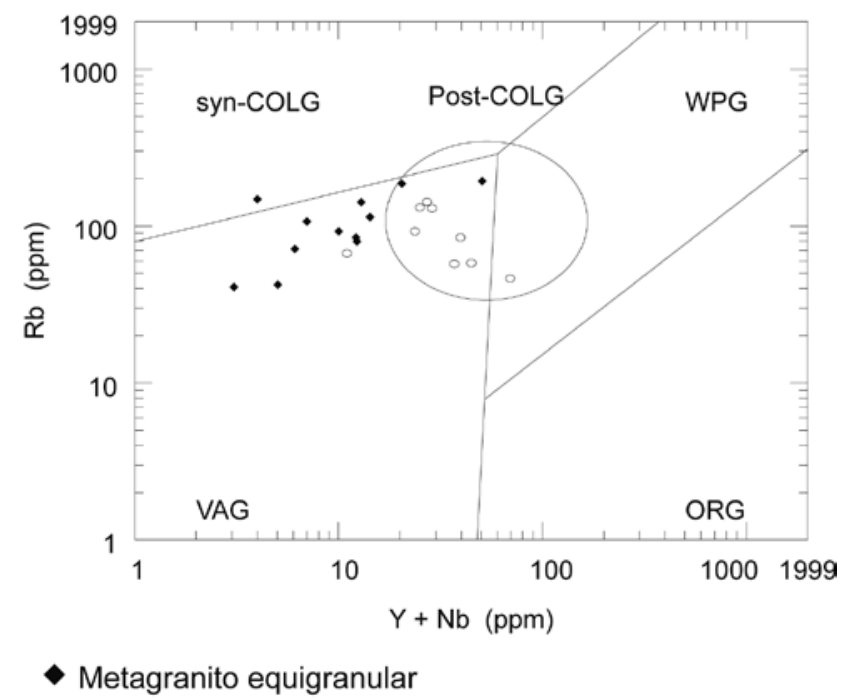

Figura 17 - Disposição dos metagranitos porfiriticos e equigranulares nos diagramas $N b x Y(a)$ e $R b \times Y+N b(b)$ de Pearce et al. (1984) com a subdivisão dos campos dos granitos intra-placa (WPG), arco vulcânico (VAG), sin-colisionais (SYN-COLG), cadeias Oceânicas (ORG) e campo circular definido para granitóides pós-colisionais (Pearce 1996).

A disposição das amostras no diagrama $\mathrm{R}_{1}-\mathrm{R}_{2}$ (De La Roche \& Leterrier 1973), modificado por Batchelor e Bowden 1985), formaram dois trends subparalelos e alinhados dentro do campo dos granitos sin-colisionais, sugerindo que as amostras analisadas evoluíram em um ambiente com forte contribuição crustal (Fig. 18).

CONSIDERAÇÕES FINAIS E CONCLUSÕES Os dados de campo e petrográficos permitiram reconhecer dois tipos de metagranitos no Complexo Encantadas: granodioritos a monzogranitos porfiríticos e monzogranitos equigranulares. A composição dos metagranitos é cálcico-alcalina médio a alto-K, com caráter levemente peraluminoso e teores relativamente elevados de álcalis principalmente nos termos equigranulares. O desenvolvimento de tendências distintas e subparalelas nos diagramas de Harker sugere que os metagranitos representam unidades petrológicas distintas. Os alinhamentos observados sugerem a atuação de processos de fracionamento e segregação mineral predominantemente de plagioclásio, biotita, zircão, apatita e subordinadamente de K-feldspato.

Os metagranitos possuem enriquecimento em ETRL e empobrecimento em ETRP como é comumente 


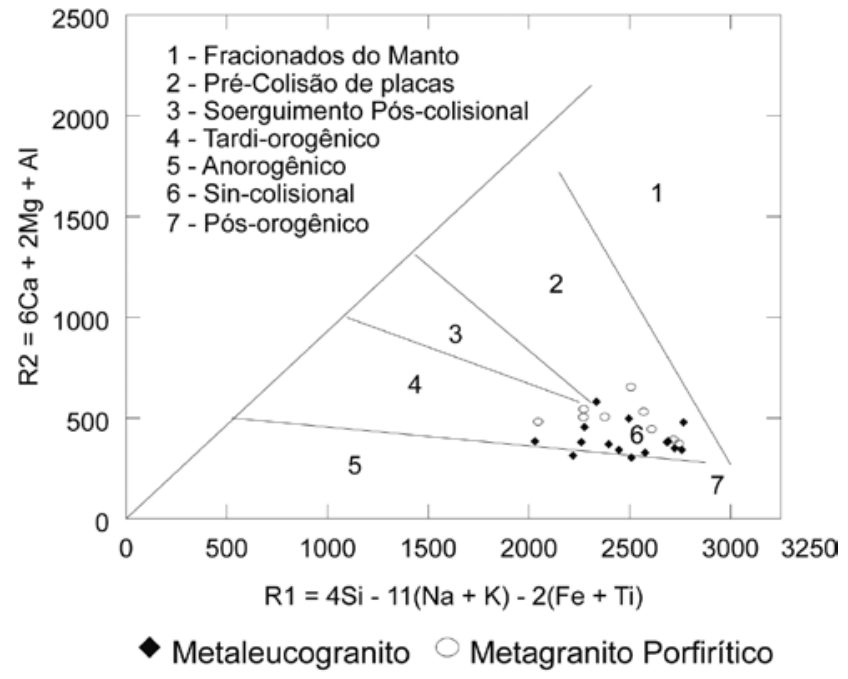

Figura 18 - Disposição dos metagranitos estudados no diagrama $R_{1}-R_{2}$ (Batchelor \& Bowden 1985).

observado em rochas de arco magmático evoluído. Os valores mais elevados LILE e de ETRL e mais baixos de ETRP sugerem uma participação crustal mais efetiva nos processos de geração do metagranito equigranular. As anomalias negativas de $\mathrm{Nb}$ em relação ao La e de Ti em relação ao Gd nos diagramas multielementares e as relações entre $\mathrm{Nb}, \mathrm{Y}$ e $\mathrm{Rb}$ sugerem que os magmas geradores das rochas graníticas sejam provenientes de fontes afetadas por subducção, vinculando estas rochas com ambientes de arco magmático maduro, como in- dicado adicionalmente pelo caráter médio a alto-K dos granitóides.

A integração dos dados petrográficos, estruturais e geoquímicos sugere que os metagranitos representam magmas de afinidade cálcico-alcalina médio a alto-K, derivados de magmatismo mantélico com participação crustal. Os dados estruturais indicam que os granitóides são pré ou sin- $\mathrm{D}_{1} \mathrm{e}$, portanto, de acordo com os dados geocronológicos disponíveis, sua idade situa-se entre 2.2 e $2.1 \mathrm{Ga}$, que é a idade presumível de cristalização ígnea. A ausência do bandamento $\mathrm{Sb}_{1}$ e a presença de uma foliação milonítica nos metagranitóides é sugestiva de que os mesmos evoluíram conjuntamente. Este magmatismo granítico mais tardio poderia estar marcando a evolução final do magmatismo que gerou o Gnaisse Encantadas, descrita por Philipp et al. (2008), ou seja, a porção mais matura da evolução de um arco Paleoproterozóico.

Os metagranitos porfiríticos e equigranulares do Complexo Encantadas em Santana da Boa Vista, Rio Grande do Sul, juntamente com os gnaisses dioriticos, tonaliticos e trondhjemiticos do mesmo complexo, descritos por Philipp et al. (2008), constituem associação magmática de ambiente de margem continental ativa, cujo magmatismo está associado a fontes mantélicas metassomatisadas por fluídos derivados de subducção litosférica durante o Paleoproterozóico.

Agradecimentos Ao Conselho Nacional de Pesquisa (CNPq) pela concessão de bolsa de produtividade em pesquisa de Ruy Paulo Philipp e Lauro Valentin Stoll Nardi. Aos revisores anônimos da Revista Brasileira de Geociências pelas sugestões e críticas ao texto final.

\section{Referências}

Batchelor R.A. \& Bowden P. 1985. Petrogenetic interpretation of granitoid rock series using multicationic parameters. Chemical Geology, 48:43-55.

Bitencourt M.F. \& Nardi L.V.S. 2004. The role of xenoliths and flow segregation in the genesis and evolution of the Paleoproterozoic Itapema Granite, a crustally derived magmas of shoshonitic affinity from southern Brazil. Lithos, 73:119.

Carvalho P.F. de. 1932. Reconhecimento geológico do Rio Grande do Sul. Rio de Janeiro, Boletim do Instituto Geológico de Mineração Brasileira, 66:1-72.

Chemale Jr. F. 2000. Evolução Geológica do Escudo Sul-riograndense. In: Holz M. \& De Ros L.F. (eds.) Geologia do Rio Grande do Sul. Porto Alegre, editora CIGO-UFRGS (Centro de Investigação do Gondwana), p. 13-52.

De la Roche H. \& LeTerrier J. 1973. Transposition du tetraedre mineralogique de Yoder et Tilley dans un diagramme chimique de classification des roches basaltique. C. R. Acad. Sci. Paris, Ser., 276:3115-3118.

Fernandes L.A., Tommasi A., Porcher C.C. 1992. Deformation patterns in the Southern Brazilian branch of the Dom Feliciano Belt: a reappraisal. Journal of South American Earth
Sciences, 5(1):77-96.

Hanson G.N. 1978. The application of trace elements to the petrogenesis of igneous rocks of granitic composition. Earth Planet. Sci. Lett., 38:26-43.

Hartmann L.A., Chemale Jr. F., Philipp R.P. 2007. Evolução geotectônica do Rio Grande do Sul no Precambriano. In: Ianuzzi R. \& Frantz J.C.. (org.) 50 anos de Geologia. Instituto de Geociências. Contribuicões. $1^{\mathrm{a}}$ ed., Porto Alegre: Editora Comunicação e Identidade, CIGO. IG-UFRGS, v. 1, p. 97-123.

Hartmann L.A., Leite J.A.D., Silva L.C., Remus M.V.D., McNaughton N.J., Groves D.I., Fletcher I.R., Santos J.C.O., Vasconcellos M.A.Z. 2000. Advances in SHRIMP geochronology and their impact on understanding the tectonic and metallogenic evolution of southern Brazil. Australian Journal Earth Sciences, 47:829-844.

Hartmann L.A., Santos J.O.S., Leite J.A.D., Porcher C.C., McNaughton N.J. 2003. Metamorphic evolution and U-Pb zircon SHRIMP geochronology of the Belizário ultramafic amphibolite, Encantadas Comnplex, southernmost Brazil. Anais da Academia Brasileira de Ciências, Rio de Janeiro, 75(3):393-403. 
Humphries S.E. 1984. The mobility of the rare earth elements in the crust. In: Henderson P. (ed.) Rare earth element geochemistry. Amsterdam, Elsevier, p. 315-341.

Irvine T.N. \& Baragar W.R.A. 1971. A guide to the chemical classification of the common volcanic rocks. Canadian Journal of Earth Sciences, 8:523-548.

Jensen L.S. 1976. A new cationic plot for classifying subalkalic volcanic rocks. Ontario Div. Mines, Miscel. Paper, v.6, 22 p.

Jost H. \& Bitencourt M.F. 1980. Estratigrafia e tectônica de uma fração da Faixa de Dobramentos Tijucas no Rio Grande do Sul. Acta Geológica Leopoldensia, São Leopoldo. 11(7):27-59.

Kuno H. 1968. Differentiation of basaltic magmas. In: Hess H.H \& Poldervaart A. (ed.) Basalts: The Poldervaart treatise on rocks of basaltic composition. New York, Intersence, v.2, p. 623-688.

Lameyre J. \& Bowden P. 1982. Plutonic rock type series: discrimination various granitoids series and related rocks. Jour. Volc. Geother. Res, 14:169-186.

Leinz V. \& H. Pinagel. 1945. Estanho e Tungstênio no Rio Grande do Sul. Boletim da Divisão de Fomento a Produção Mineral, DNPM, 70:1-80.

Le Maitre R.W. 1989. A classification of igneous rocks and glossary of terms. Oxford, Blackwell, $193 \mathrm{p}$.

Maniar P.D. \& Piccoli P.M. 1989. Tectonic discrimination of granitoids. Geological Society American Bulletin, 101:635643.

Machado R., Fragoso Cesar A.R.S., Faccini U.F. 1987. O Domo de Santana (RS): domo gnáissico manteado ou figura de interferência tipo domo e bacia. Atas. In: SBG, Simpósio Sul-Brasileiro de Geologia, 3, Curitiba, Atas, 1:167-182.

Mahood G. \& Hildreth W. 1983. Large partition coefficients for trace elements in high-silica rhyolites. Geochim. Cosmochim. Acta, 47:11-30.

Middlemost E.A.K. 1994. Naming materials in the magma/igeous rock system. Earth-Science Reviews, 37:215-224.

Pearce J.A. 1983. Role of the sub-continental lithosphere in magma genesis at active continental margins. In: Hawkesworth C.J. \& Norry M.J. (ed.) Continental basalts and mantle xenoliths. Nantwich, Chiva, p. 230-249.

Pearce J.A., Harris N.B.W., Tindle A.G. 1984. Trace element discrimination diagrams for the tectonic interpretation of granitic rocks. J. Petrology, 25:956-983.

Pearce J.A. 1996. Sources and settings of granitic rocks. Episodes, 19(4):120-125.

Philipp R.P. \& Viero A.P. 1995. Geologia dos anfibolitos associados ao Gnaisse Encantadas. Abstracts. In: Simpósio Nacional de Estudos Tectônicos, 5, Gramado, Atas, p. 67-68.

Philipp R.P., Lusa M., Nardi L.V.S. 2008. Geochemistry and petrology of dioritic, tonalitic and trondhjemitic gneisses from Encantadas Complex, Santana da Boa Vista, southernmost Brazil: a Paleoproterozoic continental-arc magmatism. Anais da Academia Brasileira de Ciências, 80(4):735-748.

Porcher C.C. \& Fernandes L.A.D. 1990. Relações Embasamento/“Cobertura" na porção Ocidental do Cinturão Dom Feliciano: um esboço estrutural. Pesquisas, 17(12):72-84.

Remus M.V.D., Philipp R.P., Faccini U.F., Junges S.L. 1990. Contribuição ao estudo geológico-estrutural dos Gnaisses Encantadas e das relações com as supracrustais Porongos na região de Santana da Boa Vista-RS. In: SBG, Congresso Brasileiro de Geologia, 36, Natal, Anais, 2:2358-2370.

Ribeiro M., Bocchi P.A., Figueiredo FP.M., Tessari R.I. 1966. Geologia da Quadrícula de Caçapava do Sul, RS. Boletim da Divisão de Fomento e Produção Mineral, DNPM, Rio de Janeiro, 127:1-232.

Soliani Jr. E. 1986. Os dados geocronológicos do Escudo Sulrio-grandense e suas implicações de ordem geotectônica. São Paulo, Tese de Doutoramento em Geociências, Universidade de São Paulo, 425p.

Streckeinsen A.L. 1976. To each plutonic rock, its proper name. Earth Science Review, 12:1-33.

Thompson R.N., Morrinson M.A., Hendry G.L., Parry S.J. 2000. An assessment of the relative roles of crust and mantle in magma genesis: an elemental approach. Phil. Trans. R. Soc. London, A310:549-590.

Yardley B.W.D. 1989. An introduction to Metamorphic Petrology. London, England, UK, Longman Scientific and Technical, 248p.

Manuscrito ID 14093

Submetido em 30 de abril de 2009 Aceito em 17 de março de 2010 